CELLI

BIOLOGY

\section{Natural molecules as modulators of epigenetic silencing in human cells for cancer care and aging}

\author{
Aleksandra Kosianova ${ }^{1}$, Vladlena Tiasto ${ }^{2}$, Margarita Yatsunskaya ${ }^{2,3}$, \\ Yuri Khotimchenko ${ }^{1}$, and Alexander Kagansky ${ }^{2 \dagger}$ \\ ${ }^{1}$ Department of Pharmacy and Pharmacology, School of Biomedicine, \\ Far Eastern Federal University, 10, Ajax Bay, Russky Island, Vladivostok, 690922, Russian Federation \\ ${ }^{2}$ Centre for Genomic and Regenerative Medicine, School of Biomedicine, \\ Far Eastern Federal University, 10, Ajax Bay, Russky Island, Vladivostok, 690922, Russian Federation \\ ${ }^{3}$ Federal Scientific Center of the East Asia Terrestrial Biodiversity, Far East Branch of \\ the Russian Academy of Sciences, pr. 100-letiya Vladivostoka, 159, Vladivostok, \\ 690022, Russian Federation
}

Address correspondence and requests for materials to Aleksandra Kosianova, kosjanova_aleksandra@icloud.com

\begin{abstract}
The etiology and pathogenesis of malignant tumor growth are associated with impaired gene expression, leading to accelerated proliferation, evasion of apoptosis, and metabolic deregulations with abnormal blood supply and innervation. Currently, hundreds of tumor suppressor genes and proto-oncogenes are known. Mutations, epigenetic alterations, exposure to viruses, and other environmental factors can cause pathological changes in gene expression. The key mechanisms of carcinogenesis are now considered to be linked to epigenetic events. A better understanding of epigenetic targets and pathways is needed to develop new strategies in antitumor chemotherapy. The majority of modern cancer drugs were taken from nature, yet only a small fraction of natural molecular diversity has been explored to date. Therefore, there is great interest in identifying new natural molecules for modulating gene expression by rewiring epigenetic pathways. This review is focused on examples of known natural molecules available to biomedicine, especially ones capable of modulating epigenetic landscapes and therefore relevant for cancer prevention and aging.
\end{abstract}

Citation: Kosianova, A., Tiasto, V.,
Yatsunskaya, M., Khotimchenko, Yu., and Kagansky, A. ${ }^{\dagger}$ 2020. Natural molecules as modulators of epigenetic silencing in human cells for cancer care and aging. Bio. Comm. 65(4): 315-330. https://doi. org/10.21638/spbu03.2020.405

Authors' information: Aleksandra Kosianova, Assistant, orcid.org/0000-00015655-5855; Vladlena Tiasto, PhD Student, orcid.org/0000-0001-6030-2543; Margarita Yatsunskaya, Researcher, orcid.org/00000002-4718-6186; Yuri Khotimchenko, Dr. of Sci. in Biology, Professor, orcid.org/00000002-6979-1934; Alexander Kagansky ${ }^{\dagger}$ orcid.org/0000-0002-6219-6892

Manuscript Editor: Alla Krasikova Department of Cytology and Histology, Faculty of Biology, Saint Petersburg State University, Saint Petersburg, Russia

Received: January 26, 2020;

Revised: May 5, 2020;

Accepted: July 15, 2020.

Copyright: (c) 2020 Kosianova et al. This is an open-access article distributed under the terms of the License Agreement with Saint Petersburg State University, which permits to the authors unrestricted distribution, and self-archiving free of charge.

Funding: This work was supported by the Russian Science Foundation (Project No. 20-15-00378)

Competing interests: The authors have declared that no competing interests exist.
Keywords: cancer, aging, natural products, silencing, methylation, histone modification, signaling pathways

\section{Epigenetic regulation and chromatin}

Epigenetic processes include changes in gene expression that happen irrespectively of alterations in DNA sequences (Schubert et al., 2015). The outcomes may have contrasting functional consequences depending on the structural organization of chromatin. For example, "open chromatin", called euchromatin, promotes gene expression, while heterochromatin ("closed chromatin") suppresses it (Sutherland et al., 2003). Furthermore, heterochromatin is involved in processes of dosage compensation, allelic imprinting, cell- and tissue-specific gene expression, and many other aspects of molecular cell biology, which are being actively researched in the last few decades. Substantial heterochromatin domains span arrays of hundreds and thousands of repeated elements as integral elements of functional centromeres in most eukaryotes (Buscaino et al., 2010). As a rule, these heterochromatic regions in most genomes lack active genes, and the transcription of genes located in the heterochromatin is inhibited because the resident DNA sequences attract chromatin-modifying activities that counteract functional assembly of the transcription machinery (Huisinga et al., 2006; Grewal et al., 2007). However, while the formation of heterochromatin on repetitive elements makes these regions transcriptionally inert, it promotes genome stability by regulating 
recombination, DNA repair, and chromosome segregation (Grewal et al., 2007). Recent experiments have made it possible to model gene expression, taking into account many factors, including nucleosome dynamics and binding of activators and repressors (Teif et al., 2011). Moreover, loss of gene expression, called epigenetic gene silencing, is one of the most frequently observed mechanisms exploited by cancer in order to modulate cell fates (Urnov et al., 2001).

DNA methylation is the most widely studied epigenetic mark, and it plays important roles in regulating gene expression and maintaining genome stability in a spectrum of species including plants, rodents, and humans (Weber et al., 2007; Qian et al., 2014; Xu et al., 2015). DNA methylation in general is defined as a biochemical process whereby a methyl group is added to DNA bases. It usually occurs on the fifth position of cytosine (C) to form 5-methyl cytosine, known as $5 \mathrm{mC}$ in the context of $\mathrm{CpG}$ dinucleotides - regions of DNA where a cytosine is followed by a guanine along the $5^{\prime} \rightarrow 3^{\prime}$ direction in both eukaryotes and prokaryotes (Weber et al., 2007; Qian et al., 2014; Xu et al., 2015).

The effect of $5 \mathrm{mC}$ is traditionally considered to interfere with transcriptional initiation, which thereby silences gene expression (Jones et al., 1999).

Posttranslational modifications of proteins are one of the main determinants of genomic functions, providing a fast, controlled and reversible response to environmental signals (Khoury et al., 2011). Such modifications can be caused by phosphorylation, nitrosylation, methylation, ubiquitylation, sumoylation, and other chemical reactions, with the most well studied ones being acetylation and methylation (Choudhary et al., 2014). Adding acetyl groups to the lysine residues in the protein is catalyzed by lysine acetyl transferases changing the charge and structure of the molecule, leading to a change in its function (Azevedo et al., 2016). In the last two decades, the acetylation of histone molecules (by histone acetyl transferases, HATs) was attracting particular interest and has been shown to be involved in the complex combinatorial regulation of local genome properties such as transcription, DNA repair and other chromosomal transactions. Histone deacetylases (HDACs) comprise a class of enzymes, reversing acetylations, responsible for epigenetic regulation of gene expression and playing critical roles in cellular processes including cell proliferation, apoptosis, differentiation, and angiogenesis. Methylation of histones can be either repressive in relation to transcription - such as methylation of histone H3 lysine-9 methylation (H3K9me), which dominates heterochromatic areas - or transcription-promoting (e.g., H3K4me) (Rea et al., 2000; Jenuwein et al., 2001). Methylation of H3K9 allows binding of specific chromodomain proteins, including HP1 (heterochromatin protein 1) variant, which interact with various key chro-

\begin{tabular}{|c|c|c|c|}
\hline $\begin{array}{l}\text { Modifica- } \\
\text { tion }\end{array}$ & $\begin{array}{l}\text { His- } \\
\text { tone }\end{array}$ & $\begin{array}{l}\text { Amino acid and } \\
\text { its position }\end{array}$ & $\begin{array}{l}\text { Some of } \\
\text { the factors involved }\end{array}$ \\
\hline \multirow{12}{*}{ Methylation } & $\mathrm{H} 1$ & K26 & $\mathrm{EZH} 2$ \\
\hline & \multirow{9}{*}{ H3 } & R2 & CARM1 \\
\hline & & K4 & MLL4, Gcn5, KAT5/Tip60 \\
\hline & & R8 & PMRT5 \\
\hline & & K9 & SUV39h1/h2, G9a \\
\hline & & R17 & CARM1 \\
\hline & & R26 & CARM1 \\
\hline & & K27 & $\mathrm{EZH} 2, \mathrm{G} 9 \mathrm{a}$ \\
\hline & & K36 & HYPB, NSD1 \\
\hline & & K79 & DOT1L/S.c. Dot1 \\
\hline & \multirow{2}{*}{$\mathrm{H} 4$} & R3 & PRMT1, PRMT5 \\
\hline & & K20 & SUV4-20/SET9 \\
\hline \multirow{16}{*}{ Acetylation } & \multirow{3}{*}{$\mathrm{H} 2 \mathrm{~A}$} & K4 & Esa1 \\
\hline & & K5 & KAT5/Tip60, Hat1, \\
\hline & & K7 & Hat1, Esa1 \\
\hline & \multirow{3}{*}{$\mathrm{H} 2 \mathrm{~B}$} & K11 & Gen5 \\
\hline & & K16 & Gcn5, Esa1 \\
\hline & & K20 & p300 \\
\hline & \multirow{6}{*}{$\mathrm{H} 3$} & K4 & Esa1 \\
\hline & & K9 & Gen5 \\
\hline & & K14 & Gcn5, KAT5/Tip60 \\
\hline & & K18 & p300 \\
\hline & & K23 & p300, CBP/Gen5 \\
\hline & & K27 & Gen5 \\
\hline & \multirow{4}{*}{$\mathrm{H} 4$} & K5 & Hat1, Tip60 \\
\hline & & K8 & Gen5, PCAF, Tip60 \\
\hline & & $\mathrm{K} 12$ & Hat1, Esa1 \\
\hline & & K16 & Gcn5, KAT5/Tip60 \\
\hline
\end{tabular}

matin modifying activities (Bannister et al., 2001; Nakayama et al., 2001). Table 1 gives a list of modifications, mostly acetylation and methylation, that sometimes are referred to as a histone code.

Of the many diseases that can be associated with epigenetic deregulations, the most common and widely studied are cancers. Cancer can occur due to the activation of oncogenes and/or repression of tumor suppressors. Numerous clinical and experimental data suggest that tumor cells generally exhibit genome-wide hypomethylation and localized hypermethylation, compared 
Table 2. HDAC inhibitor mediated biological effects

(Abbreviations: BCL, B-cell lymphoma; CDK, cyclin dependent kinase; CXCR4, chemokine (C-X-C motif) receptor 4; DSB, double strand breaks; FLIP, flice inhibitory protein; HIF, hypoxia inducible factor; IAP2, inhibitor of apoptosis; ICAM1, intercellular adhesion molecule 1; IFN c, interferon c; IL-1, interleukin 1; MCL 1, myeloid cell leukemia sequence 1; MHC, major histocompatibility complex; NF-jB, nuclear factor - jB; PP1, protein phosphatase 1; pRb, retinoblastoma protein; RECK, reversion-inducing cysteine-rich protein with Kazal motifs; ROS, reactive oxygen species; STAT, signal transducer and activator of transcription; TNF a, tumor necrosis factor a; TrX, thioredoxin; TBP2, TrX binding protein 2; VEGF, vascular endothelial growth factor; VHL, von Hippel-Lindau; uPA, urokinase plasminogen activator; XIAP, X-linked inhibitor of apoptosis.) (According to data from Manal et al., 2016)

\begin{tabular}{|c|c|}
\hline $\begin{array}{l}\text { Biological effects of } \\
\text { HDAC inhibitors }\end{array}$ & Mechanisms of their implementation \\
\hline \multirow{5}{*}{$\begin{array}{l}\text { Cell cycle arrest at G1/S or } \\
\text { G2/M phases }\end{array}$} & Induction of CDKN1A to encode p21waf1/CIP1 promoting pRb hypo-phosphorylation \\
\hline & $\begin{array}{l}\text { Repression of genes, Cyclin D and Cyclin A, to reduce CDK2 and CDK4 kinase activities and } \\
\text { hypophosphorylation of pRb }\end{array}$ \\
\hline & Induction of p27 which inhibits CDK2- and CDK4-containing complexes \\
\hline & Repression of genes for DNA synthesis, CTP synthase and thymidylate synthetase \\
\hline & $\begin{array}{l}\text { Activation of G2-phase checkpoint through heterochromatin hyperacetylation leads to abnormal } \\
\text { chromosomal segregation and fragmentation of nucleus }\end{array}$ \\
\hline \multirow{4}{*}{$\begin{array}{l}\text { Oxidative stress and DNA } \\
\text { damage }\end{array}$} & Accumulation of ROS in tumor cells to induce mitochondrial disruption \\
\hline & Downregulation of TrX (scavenger of ROS) \\
\hline & Indirect DNA damage by increased accumulation of phosphorylated histone variant, cH2AX (marker of DSB in DNA) \\
\hline & Repression of genes for DNA repair proteins, RAD51, BRAC1, BRCA2, Ku70 and Ku86 \\
\hline \multirow{2}{*}{$\begin{array}{l}\text { External pathway of } \\
\text { mediated apoptosis }\end{array}$} & Upregulation of TRAIL, DR5, Fas, Fas-L and TNFain transformed tumor cells; thus activation of Casp 8 and 10 \\
\hline & Repression of genes encoding for DR inhibitors, FLIP and IAP2 \\
\hline \multirow{3}{*}{$\begin{array}{l}\text { Mitochondrial pathway of } \\
\text { mediated apoptosis }\end{array}$} & Upregulating expression of pro-apoptotic (anti-survival) proteins of BCL2 family, namely Bid, Bim, Bmf \\
\hline & $\begin{array}{l}\text { Downregulation of expression of anti-apoptotic (pro-survival) BCL2 family proteins (BCL2, BCL-XL, BCL-w), } \\
\text { MCL-1 and XIAP }\end{array}$ \\
\hline & Gene induction for encoding mediators causing mitochondrial damage (Diablo, Casp 9, Apaf1, Cyt C and Htr A2) \\
\hline \multirow{2}{*}{ Autophagy and aging } & Overexpression of BCL-XL thereby inducing autophagy-mediated cell death \\
\hline & Aging through polyploidy and withdrawal of cell cycle \\
\hline \multirow{2}{*}{ Anti-angiogenesis } & Repression of pro-angiogenesis factors, HIF-1a, VEGF and CXCR4 \\
\hline & Upregulation of tumor suppressor VHL protein and p53 \\
\hline \multirow{3}{*}{ Immunomodulation } & $\begin{array}{l}\text { Augmenting tumor cell antigenicity by upregulating MHC class I and II proteins, costimulatory molecules } \\
\text { (CD40, CD80 and CD86) and ICAM1 }\end{array}$ \\
\hline & Inducing expression of MHC class I chain-related molecules, MICA and MICB \\
\hline & Suppression in secretion of pro-inflammatory cytokines, TNF a, IL-1 and IFNc \\
\hline \multirow{4}{*}{$\begin{array}{l}\text { Non-histone substrate } \\
\text { mediated }\end{array}$} & Hyperacetylation of transcription factors, E2F1, p53, STAT1, STAT3 and NF-jB \\
\hline & Hyperacetylation of proteins, Hsp90, a-tubulin, to induce protein degradation, cell growth inhibition, cell death \\
\hline & $\begin{array}{l}\text { Disruption of HDAC-PP1 complexes and activation of PP1 to cause irregularity in tumor cell phosphorylation } \\
\text { and acetylation }\end{array}$ \\
\hline & Disruption of aggresome pathway for degradation of misfolded protein aggregates \\
\hline
\end{tabular}

to normal cells. Interactions between DNMTs and histone methyltransferases, such as EZH2 and SETD2, play critical roles in epigenetic disruption during malignancy (Wu Zhang et al., 2017). Mechanisms by which overexpression of histone demethylase LSD1 leads or contributes to tumor formation could involve its capacity to silence tumor suppressor genes as a transcriptional co- repressor, mainly through $\mathrm{H} 3 \mathrm{~K} 4$ demethylation. In addition, non-coding RNAs, e.g., micro-RNAs (miRNAs), and long non-coding RNAs (lncRNAs) were the focus of attention in terms of epigenetic control. With the development of RNA sequencing methodologies, a number of such non-coding RNAs were identified and characterized (Hassan et al., 2015). In addition, new evidence 
has complicated the paradigm of epigenetic landscapes, suggesting the role of lipids in gene regulation (Zhdanov et al., 2015), as well as the discovery of chromatin factors involved in both repression and activation. For example, $\mathrm{H} 3.3$, a histone variant of $\mathrm{H} 3$, is commonly associated with transcription activation (Ahmad et al., 2002).

Unlike genetic mutations, epigenetic changes can be reversible. This reversibility led to the emergence of the concept of "epigenetic therapy", according to which the reactivation of epigenetically silent tumor suppressor genes can restore growth control in cancer cells (Jones et al., 2007; Marks 2010; Santos et al., 2010; Taby et al., 2010). As noted earlier, histone acetylation and deacetylation are catalyzed by specialized enzymes, namely histone (lysine) acetyltransferases (HATs/KATs) and HDACs, which affect specific tissues and genomic contexts differently (Chen et al., 2015; Venkatasubramani et al., 2015). It has long been established that many cancers are characterized by global hypoacetylation of histones (Fraga et al., 2005). Overexpression of individual HDACs is associated with reduced survival rates in numerous tumors, including colon, breast, lung and prostate cancer (West et al., 2014). In addition, the genetic knockdown of specific HDACs in these tumors caused cell cycle arrest and apoptosis.

Multiple biological effects of HDAC inhibitors are presented in Table 2.

As a result, numerous HDAC inhibitors have been clinically tested, and some have recently been approved by the FDA for use in various forms of human cancer (Ma et al., 2016). It is hoped that these HDAC inhibitors can be used in tumors that have developed resistance to conventional treatments or after a relapse of primary cancer (Bojang et al., 2014). It has been clearly demonstrated that the patterns of global acetylation of $\mathrm{H} 3$ and $\mathrm{H} 4$ correlate with the severity of prostate and other cancers, (Seligson et al., 2005) while global methylation patterns may have diagnostic and prognostic potential for a number of different tumors (Lizcano et al., 2012). Recently, the main efforts of epigenetic therapy were aimed to develop and refine inhibitors of two families of HDACs and DNMTs (Jones et al., 2007; Taby et al., 2010; Li-Ting Wang et al., 2014).

\section{Natural modulators of cellular pathways}

Natural compounds are a key source of drugs in modern biomedicine (Neergheen-Bhujun et al., 2017). Various types of natural molecules inhibiting silencing can be considered a fruitful avenue both for chemotherapy of cancers and for aging control. In the first part of our review we extensively cover the existing literature and perspectives concerning these types of molecules. In the second part we summarize other potentially interesting enzymes and their inhibitors that may join the therapeutic repertoire in the future. Recently it has been proved that natural compounds such as curcumin, epigallo- catechin gallate and resveratrol could alter epigenetic mechanisms which can lead to increased sensitivity of cancer cells to conventional agents and thus inhibit tumor growth (Li et al., 2010). A number of studies have reported on curcumin effects on HDAC expression. It is known that curcumin is also a potent HDAC inhibitor, which is more effective than valproic acid and sodium butyrate (Bora-Tatar et al., 2009). Another study has reported that levels of HDAC 1, 3, and 8 were significantly reduced by curcumin, leading to increased levels of acetylated histone H4 (Liu et al., 2005). Similarly, a significant reduction in HDAC1 and HDAC3 was observed upon treatment with curcumin (Chen et al., 2007).

Currently, more than $60 \%$ of the FDA-approved anticancer drugs are derived from natural compounds isolated from various types of organisms (Neergheen-Bhujun et al., 2017). These include plants (e.g., vincristine, vinblastine, etoposide, paclitaxel, camptothecin, topotecan, and irinotecan), marine organisms (e.g., cytarabine, aplidine, and dolastatin), and microorganisms (e.g., dactinomycin, bleomycin, and doxorubicin). A number of natural compounds relevant to cancer prevention and/or therapy have been derived from fruits and vegetables. These include: curcumin (from turmeric), resveratrol (from red grapes, peanuts, and berries), genistein (from soy), diallylsulfide, S-allylcysteine and allicin (from garlic), lycopene (from tomatoes), capsaicin (from chili peppers), diosgenin (from fenugreek), 6-gingerol (from ginger), ellagic acid (from pomegranates), ursolic acid (from apples, pears, prunes, etc), silymarin (from milk thistle), anetol (from anise, camphor, or dill), catechins and Epigallocatechin gallate (EGCG) (from green tea), eugenol (from cloves), indole-3-carbinol (from cruciferous waxes), and many others (Bhanot et al., 2011; Pratheeshkumar et al., 2012; Craig et al., 2013; Wai-Leng et al., 2013; Bailon-Moscoso et al., 2017). It has been shown that these natural compounds may change localized and global gene expression, induce apoptosis, or affect the activity of ligand-dependent receptor activators and oxidative stress modulators, leading to cell cycle shutdown, necrosis, and autophagy (Kong et al., 2012; Pratheeshkumar et al., 2012; Shukla et al., 2014). A number of studies have shown that curcumin, EGCG, resveratrol, sulforaphane, Gallic acid, genistein, 3,3'-diindolylmethane, and other natural molecules alter epigenetic processes, including DNA methylation, histone modification, chromatin remodeling, microRNA regulation, and thereby, cell fates. Examples of identified protein targets of such molecules include the activator Protein 1 (AP-1), Inhibitor of Differentiation 4 (ID4), Nuclear Factor-kappaB (NF-кB)/REL-A, Signal Transducer and Activator of Transcription (STAT)-3, 5 and 6, MYC, Runt-related transcription factor (RUNX)1, NOTCH1-4, CCAAT/Enhancer Binding Protein alpha $(\mathrm{C} / \mathrm{EBP} \alpha), \beta$-catenin (CTNNB1), Sterol Regulatory Element-Binding Protein (SREBP)-1c, members of Tu- 


\section{Polyphenols}

(Flavonoids, Xanthones, Stilbenes, Curcuminoids, Lignans)
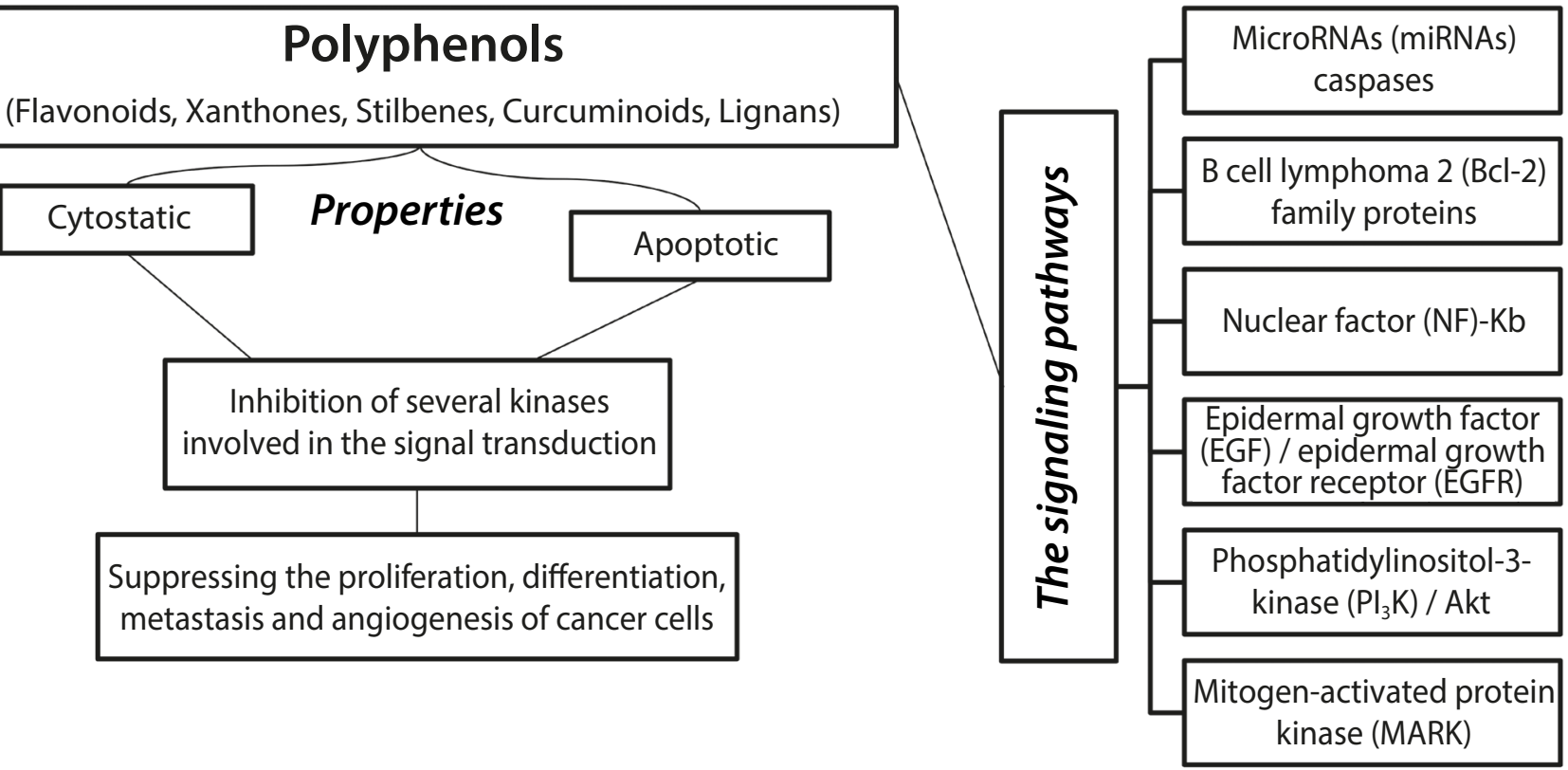

Fig. 1. The signaling pathways of polyphenols in cancer.

mor Protein (TP)-p53 family Interferon Regulatory Factor (IRF)-5, SMAD4, GLI factors, Krüppel-Like Factor (KLF)-5, MIcrophthalmia-associated Transcription Factor (MITF), PAX family members, TWIST, and Wilms' Tumor factor 1 (Lee, 2007; Kikuno et al., 2008; Andreoli et al., 2010; Lee et al., 2010; Tuntiwechapikul et al., 2010; Chen et al., 2011; Fujiwara Komohara et al., 2011; Li et al., 2011; Lee et al., 2013;).

Alkaloids and polyphenols are the predominant molecules in use for the treatment of cancer. Many natural polyphenols have cytostatic and apoptotic properties due to their antioxidant characteristics. Anti-carcinogenic activity of polyphenols includes suppression of proliferation, differentiation, metastasis, and angiogenesis of various types of cancer cells through inhibition of several kinases involved in signal transduction. Polyphenols can easily bind and cross cell membranes and interfere with various molecular mechanisms in the cell, including caspases, B cell lymphoma 2 (Bcl-2) family proteins, nuclear factor (NF)-kB, epidermal growth factor (EGF)/epidermal growth factor receptor (EGFR), phosphatidylinositol3-kinase (PI3K)/Akt, mitogen-activated protein kinase (MAPK) (Li-rui Sun et al., 2019) (Fig. 1).

We will next discuss some of the natural compounds and their targets in detail.

\section{Curcumin, EGCG, and Reservatrol and epigenetic regulation}

Curcumin (diferuloylmethane), a polyphenol from Curcuma longa, inhibits tumor cell growth and induces tumor cell death. Moreover, curcumin could modulate various signaling pathways involved with inflammation, proliferation, invasion, survival, and apoptosis (Huang et al., 1997; Teiten et al., 2010). It has been shown that curcumin induces p63 and MYC-associated factor X (MAX), and also inhibits NF- $\mathrm{kB}$ in hepatocarcinoma cells and OCT4 in pluripotent cells of embryonal carcinoma of the placenta (NCCIT). Some scientists suggest that these genes could act as potential therapeutic targets, especially in cancer stem cells. (Zang et al., .2014; Marquardt et al., 2015). Recent studies have found that curcumin lowers the activity of NF- $\kappa \mathrm{B}$ and NOTCH1 in human hematopoietic Raji cells by inhibiting the interaction of histone deacetylases (e.g., HDAC1, HDAC3) with E1A-binding protein 300 (EP300) and their binding with cAMP response element. Also, curcumin could modulate the expression of transcription factor components AP-1, c-FOS, and c-JUN (Mukhopadhyay et al., 2001; Park et al., 2005; Prusty et al., 2005; Chen et al., 2007; Lin et al., .2007). Curcumin had caused DNA damage and led to apoptosis in p73 and p53-deficient human hepatoma cells Hep3B (Wang et al., .2015). It was found that curcumin induces global and sequence-specific demethylation of the epigenetically silenced genes in human leukemia cells (Liu et al., 2009). Consistent with this, an in silico study has shown that curcumin could covalently block the catalytic thiol group in the C1226 DNMT1 binding site (Medina-Franco et al., 2011).

Tea polyphenols isolated from green tea Camellia sinensis include epicatechin, epicatechin-3-gallate (EGCG), epigallocatechin and epigallocatechin-3-gallate. Epicatechin gallate induced tumor cell death by activating TP53 and stimulating mitogen-activated protein kinase p38 (MAPK) and c-Jun N-terminal kinases 
(JNK) in human colon cancer cells in vitro (CorderoHerrera et al., 2013). The main polyphenols in black tea are: catechins, flavonoids, methylxanthines, theaflavins, and thearubigins (Siddiqui et al., 2006). The compound Polyphenon- $\mathrm{B}$, isolated from black tea, suppressed the growth of hepatocellular carcinomas in rats (induced by 3,3'-diaminobenzidine), while simultaneously reducing the expression of hypoxia-induced factor (HIF) $-1 \alpha$ and increasing HDAC1 levels (Murugan et al., 2009). Several studies have reported the inhibitory effects of tea polyphenols on DNA methylation in ovarian, oral, esophageal, breast, stomach, prostate, skin, colorectal, pancreatic and head and neck cancers. (Fang et al., 2007; Dou, 2009; Link et al., 2010; Pandey et al., 2010; Ho E. et al., 2011; Henning et al., 2012, 2013; Gerhauser, 2013; Saha et al., 2013).

Recent structural and molecular modeling studies have shown that the structures of D - and B-cycles of tea polyphenols (EGCG, for example) inhibit the DNMTs activity (Lee et al., 2005). It has been shown that EGCG bind Pro-1223, Glu-1265, Cys-1225, Ser-1229, and Arg-1309 in the catalytic pocket of DNMT1 protein. (Lee et al., 2005; Thakur et al., 2014). Catecholcontaining polyphenols inhibit DNMTs by increasing the o-methylation of SAM by the enzyme catechol-Omethyltransferase, direct inhibition of the enzyme dihydrofolate reductase activity, disruption of the folate cycle and increased SAM levels, and direct inhibition of DNMTs [Lee et al., 2005; Thakur et al., 2014). It has been reported that EGCG reverse hypermethylation of Cdkn2a, retinoic acid receptor- $\beta$ (Rarß), O-6-methylguanine-DNA-methyltransferase (MGMT), and MutL Homolog-1 (MLH1) genes by inhibiting DNMT1 activity in human esophageal cancer KY55 cells by binding to the DNMT1 catalytic pocket and by inhibiting its enzyme activity (Lu et al., 2007; Xiao et al., 2007; Gao et al., 2009). Also, EGCG inhibits DNMTs activity and reactivate the Rarß gene suppressed by methylation in human colon and prostate cancer cells (Lee et al., 2005). EGCG could demethylate the promoter regions of DNA of genes encoding annexin A1 (ANXA1) and inhibit Wnt1(WIF1) factor in lung cancer cells (Lu et al., 2007; Xiao et al., 2007; Gao et al., 2009). Exposure of human epidermoid carcinoma A431 cells to EGCG decreased global levels of DNA methylation and activity and DNMT proteins DNMT1, DNMT3A, and DNMT3B (Nandakumar et al., 2011). At the same time, it was discovered that EGCG reactivated silenced CDKN1A and CDKN2A (Nandakumar et al., 2011). Effects of green tea-derived EGCG have been demonstrated in cancer cells of the esophagus, oral cavity, skin, lungs, breast, and prostate cancer models (Henning et al., 2013). Transcription factors (e.g., NF- $\mathrm{BB}, \mathrm{AP}-1, \mathrm{CREB}$, and HIF-1 $\alpha$ ) were suppressed in mouse melanoma cells when treated with a combination of EGCG with dacarbazine or quer- cetin with sulforaphane (Liu et al., 2001; Pradhan et al., 2010; AlQathama et al., 2015; Feitelson et al., 2015).

Resveratrol [3, 5, 4'-trihydroxy-trans-stilbene] is a natural polyphenol from blueberries, mulberries, cranberries, peanuts, and grapes. It was shown that resveratrol has a pronounced anticancer potential. Resveratrol inhibits the transmission of Hifla-mediated androgen receptor signals and reduces the proliferation of prostate cancer cells in vitro and tumor progression in vivo (Mitani et al., 2014). A recent study showed that resveratrol works to inhibit the development of pancreatic cancer in KRAS mutant mice (Shankar et al., 2011). It has been further discovered that resveratrol induces apoptosis in human cancer stem cells, activating caspase-3/7 and inhibiting the expression of BCL-2 and XIAP proteins (Shankar et al., 2011; Wang et al., 2013). Resveratrol inhibits the expression of metastasis associated protein-1 (MTA1), a known component of the nucleosome remodeling and deacetylation complex NuRD, which is overexpressed in some cancer types, including prostate cancer (Kai et al., 2010; Dhar et al., 2015; Levenson et al., 2015). As a result of MTA1 expression inhibition, resveratrol interfered with MTA1 / HDAC1 interaction in the NuRD co-repressor complex, causing increased TP53 expression and acetylation, which subsequently led to an increase in Bax and p21 expression, leading to apoptosis in prostate cancer cells (Kai et al., 2010; Levenson et al., 2014; Dhar et al., 2015). Pterostilbene found in blueberries, a natural resveratrol derivative, has also been found to greatly increase the MTA1-mediated TP53 acetylation (Li et al., 2013). Resveratrol and pterostilbene were also found to suppress tumor growth, progression, local invasion, and spontaneous metastases in orthotopic prostate cancer xenografts in another study (Li et al., 2013). Resveratrol inhibited HDAC1, HDAC2, MTA1, MTA2, and MTA3 proteins of NuRD complex in prostate cancer DU145 cells and activated the PTEN tumor suppressor by increasing its acetylation, which led to the inhibition of the AKT signaling pathway in prostate cancer (Levenson et al., 2014; Dhar et al., 2015). It has been further shown that resveratrol induces autophagy by activating NAD-dependent deacetylase, SIRT1 (Cherblanc et al., 2013). However, other phenolic compounds found in red wine, including anthocyanins (ENIN), stilbenoid (piceatannol), phenols (gallic acid), glycosides (delphinidin, kuronen, peonidin), and flavonoids (catechin, epicatechin, quercetin, myrinet) were also shown to promote autophagy (Pietrocola et al., 2012). Resveratrol is selective for the class III HDACs such as SIRT1, SIRT2, SIRT3, as well as for the HAT, EP300 (Pietrocola et al., 2012). Also, resveratrol could induce prostate cancer cell death in vitro by the modulation of global gene expression rates through deacetylation of FOXO transcription factor in human pancreatic and prostate cancer cells in vitro and in vivo 
Table 3. Effects of natural compounds on epigenetic and antitumor activity

\begin{tabular}{|c|c|c|c|}
\hline Natural compounds & Source & Epigenetic/cellular effect & Anticancer effect \\
\hline $\begin{array}{l}\text { Polyphenols: } \\
\text { Resveratrol }\end{array}$ & Grapes, peanuts & $\begin{array}{l}\text { DNMT 3b inhibitor; decrease in RASSF-1a } \\
\text { methylation with increasing circulating } \\
\text { resveratrol; Suppress expression of the } \\
\text { androgen receptor }\end{array}$ & $\begin{array}{l}\text { Decreased risk of prostate cancer } \\
\text { and breast cancer }\end{array}$ \\
\hline Polyphenols: Genistein & Soybeans & $\begin{array}{l}\text { Suppress expression of the androgen receptor } \\
\text { (ER- } \beta \text { ); inhibition of DMNT; demethylation of } \\
\text { RAR } \beta, \text { p } 16 \text { and MGMT promoters; demethylation } \\
\text { of promoters of miR-29a and miR-1256 }\end{array}$ & $\begin{array}{l}\text { Inhibition of prostate cancer } \\
\text { cell proliferation and invasion; } \\
\text { decreased risk of prostate cancer } \\
\text { and breast cancer }\end{array}$ \\
\hline $\begin{array}{l}\text { Polyphenols: } \\
\text { Epigallocatechin- } \\
\text { 3-gallate }\end{array}$ & Green tea & $\begin{array}{l}\text { Demethylation and/or suppressed } \\
\text { methylation of TSG promoters (p15 and p16); } \\
\text { inhibits HDAC activity. }\end{array}$ & $\begin{array}{l}\text { Antioxidant activity; inhibition } \\
\text { of angiogenesis; induction of } \\
\text { apoptosis; inhibited invasive } \\
\text { metastasis in a human pancreatic } \\
\text { adenocarcinoma cell line }\end{array}$ \\
\hline Isothiocyanates & Cruciferous vegetables & $\begin{array}{l}\text { Interaction with xenobiotic compounds, } \\
\text { smoking and consumption of cruciferous } \\
\text { vegetables }\end{array}$ & $\begin{array}{l}\text { Anti-cancer effect: induced } \\
\text { apoptosis and suppressed } \\
\text { metastatic potential in lung cells. }\end{array}$ \\
\hline Folate & $\begin{array}{l}\text { Periconceptional folic } \\
\text { acid supplementation; } \\
\text { dark green leafy } \\
\text { vegetables }\end{array}$ & $\begin{array}{l}\text { Higher IGF2 methylation in offspring; higher } \\
\text { hMLH1 promoter methylation }\end{array}$ & $\begin{array}{l}\text { Lower birth weight; association } \\
\text { with colorectal cancer risk }\end{array}$ \\
\hline a linoleic acid & Flaxseed & $\begin{array}{l}\text { Decreased expression of COX } 1 \text { and COX } 2 \\
\text { when fed to male Fischer rats; Decreased } \\
\text { COX } 2 \text { expression when fed to hens; Changed } \\
\text { expression of genes associated with brain }\end{array}$ & $\begin{array}{l}\text { Tumor incidence, multiplicity and } \\
\text { size decreased; reduction in ovarian } \\
\text { cancer incidence and severity; } \\
\text { influence on brain development }\end{array}$ \\
\hline Trans fatty acids & $\begin{array}{l}\text { Industrially processed } \\
\text { foods and low levels in } \\
\text { meat }\end{array}$ & $\begin{array}{l}\text { DNA hypomethylation in the brains } \\
\text { of offspring; histone modifications; } \\
\text { hypomethylation at the Sacll site in the ER gene } \\
\text { in response to a diet high in omega } 6 \text { PUFA }\end{array}$ & $\begin{array}{l}\text { During seven years of follow-up } \\
\text { serum trans MUFA levels were } \\
\text { associated with risk of invasive } \\
\text { breast cancer }\end{array}$ \\
\hline
\end{tabular}

(Chen et al., 2010; Ganapathy et al., 2010; Roy et al., 2011). Stemness transcription factors, namely NANOG, SOX2, c-MYC, and OCT4, were also inhibited by resveratrol, curcumin, and epigallocatechin-3-gallate in human cancer stem cells (Shankar et al., 2011; Ding et al., 2013; Wang et al., 2013; Yoon et al., 2014).

Effects of natural compounds on epigenetic and antitumor activity are shown in Table 3.

\section{Rapamycin, metformin, and aging}

For a long time, aging was considered an unforgiving road to decline and disease, but more recently, with the advancement of molecular and cellular insight into biology of the related processes, it is becoming evident that aging is plastic. Such plasticity could be used to approach aging of an organism and age-related diseases from a new perspective. In particular, aging is associated with deep epigenetic changes leading to changes in gene expression and disturbances in the broad genome architecture and epigenomic landscape. Although many studies have focused on genes involved in aging and the related diseases, the non-genetic regulation of aging is attracting increasing attention. The potential reversibility of these epigenetic changes, which occur as a sign of aging, offers exciting opportunities to change the trajectory of age-re- lated diseases. Metformin and rapamycin are two FDAapproved mTOR inhibitors exhibiting significant anticancer and antiaging properties beyond their current clinical use. However, each one faces problems with approval due to side effects. These two drugs are also discussed in the context of caloric restriction as mimetics (Ingram et al., 2004). Caloric restriction is a well-known intervention to increase longevity in various species (Mattison et al., 2017), but it may have limited practical value to humans (Phelan et al., 2005). Caloric restriction mimetics will theoretically have their beneficial effects without actually reducing calorie intake. The hallmarks of calorie restriction are reduced circulating glucose and insulin levels, as well as responses to these reductions in nutrition and energy-sensitive networks, such as activation of AMPactivated protein kinase (AMPK) and inhibition of mammalian rapamycin target (mTOR) (Zhavoronkov, 2015). The mTOR pathway is particularly important, being essential for early development, but also potentially damaging in later years if not suppressed, contributing to cellular aging and disease (Blagosklonny, 2015). Inhibition of the mTOR pathway slows conversion to aging (Blagosklonny, 2015) and prolongs life expectancy in different species (Fabrizio et al., 2001; Vellai et al., 2003; Jia et al., 2004). Rapamycin and metformin, although different in clinical application, are both mTOR inhibitors and have multiple 
anti-aging, anti-cancer, and cardiovascular benefits (Roth et al., 2016). Rapamycin (sirolimus) is an immunosuppressant used after kidney transplantation. It has been shown to reduce the risk of cancer after surgery in kidney transplant patients (Campistol et al., 2006; Yakupoglu et al., 2006; Garrick, 2007). Although the extent to which rapamycin's anti-cancer properties underlie its anti-aging action and/or vice versa remains a matter of debate (Blagosklonny 2015; Leontieva et al., 2015), it has also been reported or theorized to protect against a number of other aging-related diseases in humans with cardiovascular disease, osteoporosis, obesity, autoimmune diseases and arthritis, macular degeneration, diabetes, Alzheimer's disease and Parkinson's disease. While rapamycin interacts with various pathways associated with the transmission of nutritional signals, it acts primarily through direct interaction of the mTOR 1 complex (mTORC1) (Roth et al., 2016; Blagosklonny, 2017).

Through a combination of AMPK-dependent and -independent mechanisms (Zhou et al., 2001), metformin affects a number of signaling pathways, including IGF-1 (Lib et al., 2011), Sirtuin 1 (SIRT1) (Arunachalam et al., 2014; Zhong et al., 2015), and mTOR complex 1 (mTORC1) (Howell et al., 2017), which contribute directly or indirectly to its clinical response and multiple antitumor effects. Taken together, rapamycin and metformin are promising candidates for increased longevity and health; however, concerns about side effects prevent their widespread use for this purpose. Although shortterm use of rapamycin is considered safe, side effects such as wound complications, oral ulcers, diarrhea, hypokalemia, bronchopneumonia, proteinuria and withdrawal syndrome are possible.

Metformin, although relatively safe, is poorly tolerated in one quarter to half of patients due to gastrointestinal side effects (Dujic et al., 2016). Given the urgent need for the prevention of aging and the prevention of diseases associated with it, it would be useful to consider natural alternatives such as nutraceuticals that would be safe enough for widespread use (Nasri et al., 2014).

The central question is whether epigenetic drugs will solve the problem of age-related diseases that accumulate in the elderly. Thus, it will be worthwhile to test epigenetic drugs for several age-related diseases (Brunet et al., 2014).

\section{Other natural small molecules and cancer epigenetics}

Other natural molecules have striking effects relevant for cancer research. For example, sulforaphane induces anticancer activity and enhances xenobiotics metabolism, causing cell cycle arrest and apoptosis in human cancer cells (Clarke et al., 2008). Sulforaphane reduced the enzymatic activity of DNMT1 and DNMT3A and demethyl- ated the first exon of the human TERT gene in human colon cancer cells and in breast cancer cells (Traka et al., 2005; Meeran et al., 2010). It was found that sulforaphane and 3,3'-diindolylmethane induced the reactivation of tumor suppressor genes suppressed in cancer cells by DNA methylation (Kaufman-Szymczyk et al., 2015). Also, it has been shown that both sulforaphane and 3,3'-diindolylmethane could reduce the expression of DNA methyltransferases, leading to general hypomethylation of promoters in androgen-dependent and -independent human prostate cancer cells (Wong et al., 2014). Interestingly, sulforaphane and 3,3'-diindolylmethane have common gene targets that are actively involved in the progression of the same type of cancer (Wong et al., 2014). Phenethylisothiocyanate was found to inhibit growth and induce apoptosis in cancer cells (Cheung et al., 2010). Human prostate cancer cells exposed to phenethylisothiocyanate demonstrated demethylation of the GSTP1 gene promoter, reduced HDAC activity and activated acetylation and methylation of histones at specific loci (Wang et al., 2007). Indole-3-carbinol is purified from the representatives of the cruciferous family (Brassicaceae), including broccoli, cabbage, cauliflower, mustard, and radish. In the acidic environment of the stomach, indole-3-carbinol is converted into diindolylmethane. Both indole-3-carbinol and diindolylmethane induced apoptosis in various cancer cell lines by modulation of nuclear receptor mediated signals (Rahman et al., 2006; Banerjee et al., 2011; Chen et al., 2012; Safa et al., 2015). Indole-3-carbinol inhibits NF- $\kappa B$ activity and stimulates the p53-dependent pathway and its downstream target genes and activates apoptotic protease factor (APAF) -1 in acute lymphoblastic leukemia cells (MDA-MB-231 and MCF-7) by suppressing STAT3 and NF- $\kappa B$ signaling (Chung et al., 2015). Kukurbitatsin B from Hemsleya endecaphylla reduced tumor cell proliferation and induced their apoptosis through modulating the STAT3 pathway in the human lung cancer cell line (Zhang et al., 2014). It has been reported that a compound from Eurycoma longifolia, eurycomanone, inhibited the viability and proliferation of Jurkat and K562 cells but didn't have such an effect on benign cells (Orlikova et al., 2013; Hajjouli et al., 2014). Strikingly, eurycomanone repressed the NF-KB signaling by inhibiting $\mathrm{IkB}$ phosphorylation and signaling by the mitogenactivated protein kinase (Orlikova et al., 2013; Hajjouli et al., 2014). Aaptamine from the marine sponge Aaptos sp. was shown to reduce the proliferation of various human cancer cell types by modulating AP- 1, NF- $\kappa \mathrm{B}$, and $\mathrm{p} 53-$ dependent transcription activity (Dyshlovoy et al., 2014). Codenomicon, a sesquiterpene lactone from Chloranthus henryi, inhibits cancer cell invasion, migration, and metastasis of breast cancer cells, inhibiting RUNX2 transcriptional activity (Wang W et al., 2014). Kirstin from Uncaria rhynchophylla is an anti-metastatic phytochemical that inhibits the invasion of breast cancer cells through 
targeting of NF- $\mathrm{KB}$ factor for activation (Lou et al., 2014). Bergamottin is a natural furanocoumarin from grapefruit juice that promotes the apoptosis of myeloma cells via inhibiting the STAT3 signaling (Kim et al., 2014). Annona muricata extract induced cell cycle arrest and apoptosis in A549 cells by activating mitochondrial mediated signaling and suppressing nuclear translocation of NF- $\mathrm{BB}$ (Moghadamtousi et al., 2014).

Ethanol extracts of Piriformospora indica roots significantly increased the expression of TP53 protein in human nasopharyngeal carcinoma cells in a time- and dose-dependent manner (Kao et al., 2015). It has been further shown that grifolin from Albatrellus confluens fungus induced cell cycle arrest in various human cancer cells by targeting extracellular signal-regulated kinase 1 or by activating the death-associated protein kinase (DAPK) -1 via regulating TP53 transcription (Luo et al., 2015). Chalcons are natural compounds from various spices, tea, beers, fruits and vegetables, which can modulate transcription factors employed by key cancer pathways, including TP53, NF-KB, STAT3, AP-1, NRF2, and Wnt (Jandial et al., 2014). It was found that the herbal alkaloid carbazole mahanine activates TP53 protein, which leads to the accumulation of reactive oxygen species in the nucleus. It also affects PTEN and its interaction with TP53 / TP73 proteins in colorectal cancer cells, and it was also shown to inhibit STAT3 expression in cervical cancer cells (Das et al., 2014).

Dehydroleucodine from Gynoxys verrucosa (Ecuador) caused cell cycle arrest, apoptosis, and DNA damage in human astrocytoma cells (Bailón-Moscoso et al., 2015). Enhanced expression of the cyclin-dependent kinase inhibitor (CDKN1A) and protein BAX, as well as the phosphorylation of proteins TP53, TP73, and $\gamma$-H2AX in cancer cells exposed to dihydrocodeine resulted in cell death (Bailón-Moscoso et al., 2015). Z-ligustilide from Radix Angelicae Sinensis restored Nrf2 gene expression as well as Nrf2 downstream genes (e.g., HO1, NQO1 and UGT1A1) in breast cancer cells (Su et al., 2013). Treatment with Z-ligustilide inhibited DNMT activity in vitro and reduced the level of methylation of the Nrf2 promoter region. This study demonstrated that Nrf2 expression is likely to be epigenetically controlled, and this control was affected by natural compounds, allowing the prevention of carcinogenesis in the TRAMP mouse prostate cancer model (Su et al., 2013). Trichostatin A from actinomycete Streptomyces hygroscopicus is a potent inhibitor of pan-HDAC activity and has been found to induce apoptosis by increasing BAX and CASP3 protein levels, also reducing the telomerase expression (TERT) (Woo et al., 2007). It was discovered that depsipeptide FK228 from Chromobacterium violaceum specifically inhibited class I HDACs, inducing apoptosis of leukemic human cells (Furumai et al., 2002; Konstantinopoulos et al., 2006). In addition, FK228 induced the autophagy pathway and translocation of the apoptosis-in- duced factor (AIF) from mitochondria to the nucleus. This compound was approved by the FDA for the treatment of cutaneous T-cell lymphomas as Istodax.

Our recent study identified three endemic plants from Mauritius affecting the cell cycle of human oesophageal squamous carcinoma cells (Rummun et al., 2019). Treatment with extracts of these plant leaves induced AMPK pathway activation (Rummun et al., 2019). More research is necessary to identify and test the effector molecules in these extracts, as well as their exact mechanisms of action. A promising path to new anticancer therapies is building cell-based systems for phenotypic screening of natural extracts made from various species, e.g., ones used in traditional medicine. For example, such phenotype-based models make it possible to identify small molecules affecting HDACi and DNMTi and other major epigenetic regulators.

\section{Concluding remarks}

Reversibility of epigenetic changes could open up exciting opportunities for age-related diseases. An important goal for the future will be the identification of epigenetic drugs to reverse the epigenetic changes which occur as a sign of aging and aging diseases such as cancer. Several specific compounds have been developed which target enzymes responsible for epigenetic changes and are in clinical trials for testing for some age-related diseases, including cancer. A key challenge in this approach will be to develop additional drugs that specifically affect epigenetic pathways and test existing drugs on wellstudied animal models.

Overall it is now well established that a variety of natural compounds can be used to modulate epigenetic regulatory mechanisms in tumor cells, enhancing or inhibiting epigenetic regulators to change gene regulation, and therefore control the expression of a large number of proteins and their properties. As a result, such epigenetic interference may induce cell cycle arrest, cell differentiation or cell death via apoptosis, necrosis, autophagy, or mitotic catastrophe in tumor cells as well as shape the microenvironment of the tumor (Yu et al., 2010). However, further in-depth studies are needed to determine the contribution of epigenetic changes caused by natural compounds in various human cancers. A better understanding of epigenetic targets and pathways altered by natural compounds is needed to develop new strategies in chemoprevention, including their combinations with chemotherapy currently in use, as well as their anti-aging applications.

\section{References}

Abdelfatah, E., Kerner, Z., Nanda, N., and Ahuja, N. 2016. Epigenetic therapy in gastrointestinal cancer: the right combination. Therapeutic Advances in Gastroenterology 9(4):560579. https://doi.org/10.1177/1756283X16644247 
Adam, S. and Polo, S. E. 2014. Blurring the line between the DNA damage response and transcription: the importance of chromatin dynamics. Experimental Cell Research 329(1):148-53. https://doi.org/10.1016/j.yexcr.2014.07.017

Ahmad, K. and Henikoff, S. 2002. The histone variant H3.3 marks active chromatin by replication-independent nucleosome assembly. Molecular Cell 9(6):1191-200. https://doi.org/10.1016/S1097-2765(02)00542-7

AlQathama, A. and Prieto, J. M. 2015. Natural compounds with therapeutic potential in melanoma metastasis. Natural Product Reports 32(8):1170-1182. https://doi. org/10.1039/c4np00130c

Andreoli, V., Gehrau, R. C., and Bocco, J. L. 2010. Biology of Krüppel-like factor 6 transcriptional regulator in cell life and death. IUBMB Life 62(12):896-905. https://doi. org/10.1002/iub.396

Azevedo, C. and Saiardi, A. 2016. Why always lysine? The ongoing tale of one of the most modified amino acids. Advances in Biological Regulation 60:144-150. https://doi. org/10.1016/j.jbior.2015.09.008

Bailon-Moscoso, N., Cevallos-Solorzano, G., Romero-Benavides, J. C., and Orellana, M. 2017. Natural compounds as modulators of cell cycle arrest: application for anticancer chemotherapies. Current Genomics 18(2):106-131. https://doi.org/10.2174/1389202917666160808125645

Bailón-Moscoso, N., González-Arévalo, G., Velásquez-Rojas, G., Malagon, O., Vidari, G., Zentella-Dehesa, A., Ratovitski, E. A., and Ostrosky-Wegman, P. 2015. Phytometabolite dehydroleucodine induces cell cycle arrest, apoptosis, and DNA damage in human astrocytoma cells through p73/p53 regulation. PLoS One 10(8):e0136527. https://doi.org/10.1371/journal.pone.0136527

Bajpe, P. K., Prahallad, A., Horlings, H., Nagtegaal, I., Beijersbergen, R., and Bernards, R. 2014. A chromatin modifier genetic screen identifies SIRT2 as a modulator of response to targeted therapies through the regulation of MEK kinase activity. Oncogene 34(4):531-536. https:// doi.org/10.1038/onc.2013.588

Banerjee, S., Kong, D., Wang, Z., Bao, B., Hillman, G. G., and Sarkar, F. H. 2011. Attenuation of multi-targeted proliferation-linked signaling by 3,3'-diindolylmethane (DIM): from bench to clinic. Mutation Research 728(1-2):47-66. https://doi.org/10.1016/j.mrrev.2011.06.001

Bannister, A.J., Eckerman, P., Partridge, J.F., Miska, E. A., Thomas, J. O., Allshire, R. C., and Kouzarides, T. 2001. Selective recognition of methylated lysine 9 on histone H3 by HP1 chromo domain. Nature 410:120-124. https:// doi.org/10.1038/35065138

Berletch, J. B., Liu, C., Love, W. K., Andrews, L. G., Katiyar, S. K., and Tollefsbol, T. O. 2008 Epigenetic and genetic mechanisms contribute to telomerase inhibition by EGCG. Journal of Cellular Biochemistry 103(2):509-519. https://doi. org/10.1002/jcb.21417

Bhanot, A., Sharma, R., and Malleshappa, N. 2011. Natural sources as potential anti-cancer agents: A review. International Journal of Phytomedicine 3:9-26.

Bishop, K. and Ferguson, L. 2015. The interaction between epigenetics, nutrition and the development of cancer. Nutrients 7:922-947. https://doi.org/10.3390/nu7020922

Bojang, P.Jr. and Ramos, K.S. 2014.The promise and failures of epigenetic therapies for cancer treatment. Cancer Treatment Reviews 40(1):153-169. https://doi. org/10.1016/j.ctrv.2013.05.009

Bora-Tatar, G., Dayangac-Erden, D., Demir, A.S., Dalkara, S., Yelekci, K., and Erdem-Yurter, H. 2009. Molecular modifications on carboxylic acid derivatives as potent histone deacetylase inhibitors: Activity and docking studies. Bio- organic \& Medicinal Chemistry 17:5219-5228. https://doi. org/10.1016/j.bmc.2009.05.042

Brunet, A. and Berger, S. L. 2014. Epigenetics of aging and aging-related disease. The Journals of Gerontology. Series A, Biological Sciences and Medical Sciences 69(S1):S17-S20. https://doi.org/10.1093/gerona/glu042

Buscaino, A., Allshire, R., and Pidoux, A. 2010. Review of the building the centromere: home sweet home or a nomadic existence? Current Opinion in Genetics \& Development 20(2):118-126. https://doi.org/10.1016/j. gde.2010.01.006

Chen, C. C., Chen, H. L., Hsieh, C. W., Yang, Y. L., and Wung, B. S. 2011. Upregulation of NF-E2-related factor-2-dependent glutathione by carnosol provokes a cytoprotective response and enhances cell survival. Acta Pharmacologica Sinica 32(1):62-69. https://doi.org/10.1038/aps.2010.181

Chen, D., Banerjee, S., Cui, Q. C., Kong, D., Sarkar, F. H., and Dou, Q. P. 2012. Activation of AMP-activated protein kinase by 3,3'-Diindolylmethane (DIM) is associated with human prostate cancer cell death in vitro and in vivo. PLoS One. 7(10):e47186. https://doi.org/10.1371/journal. pone.0047186

Chen, H. P., Zhao, Y. T., and Zhao, T. C. 2015. Histone deacetylases and mechanisms of regulation of gene expression. Critical Reviews in Oncogenesis 20(1-2):35-47. https://doi. org/10.1615/CritRevOncog.2015012997

Chen, Q., Ganapathy, S., Singh, K. P., Shankar, S., and Srivastava, R. K. 2010. Resveratrol induces growth arrest and apoptosis through activation of FOXO transcription factors in prostate cancer cells. PLoS One 5(12):e15288. https://doi.org/10.1371/journal.pone.0015288

Chen, Y., Shu, W., Chen, W., Wu, Q., Liu, H., and Cui, G. 2007. Curcumin, both histone deacetylase and p300/CBPspecific inhibitor, represses the activity of nuclear factor kappa B and Notch 1 in Raji cells. Basic \& Clinical Pharmacology \& Toxicology 101:427-433. https://doi. org/10.1111/j.1742-7843.2007.00142.x

Cherblanc, F. L., Davidson, R. W., Di Fruscia, P., Srimongkolpithak, N., and Fuchter M. J. 2013. Perspectives on natural compound epigenetic modulators in chemical biology and medicine. Natural Product Reports 30(5):605-624. https://doi.org/10.1039/c3np20097c

Cheung, K. L. and Kong, A. N. 2010. Molecular targets of dietary phenethyl isothiocyanate and sulforaphane for cancer chemoprevention. The AAPS Journal 12(1):87-97. https://doi.org/10.1208/s12248-009-9162-8

Choi, J. H., Kwon, H. J., Yoon, B. I., Kim, J. H., Han, S. U., Joo, H. J., and Kim, D.Y. 2001. Expression profile of histone deacetylase 1 in gastric cancer tissues. Japanese Journal of Cancer Research 92(12):1300-1304. https://doi. org/10.1111/j.1349-7006.2001.tb02153.x

Choudhary, C., Weinert, B. T., Nishida, Y., Verdin, E., and Mann, M. 2014. The growing landscape of lysine acetylation links metabolism and cell signalling. Nature Reviews. Molecular Cell Biology (8):536-550. https://doi.org/10.1038/ nrm3841

Chung, S. S. and Vadgama, J. V. 2015. Curcumin and epigallocatechin gallate inhibit the cancer stem cell phenotype via down-regulation of STAT3-NFKB signaling. Anticancer Research 35(1):39-46.

Clarke, J. D., Dashwood, R. H., and Ho, E. 2008. Multi-targeted prevention of cancer by sulforaphane. Cancer Letters 269(2):291-304. https://doi.org/10.1016/j.canlet.2008.04.018

Cordero-Herrera, I., Martín, M. A., Bravo, L., Goya, L., and Ramos, S. 2013. Epicatechin gallate induces cell death via p53 activation and stimulation of p38 and JNK in human colon cancer SW480 cells. Nutrition and Cancer 
65(5):718-728. https://doi.org/10.1080/01635581.2013. 795981

Darnell, J. E. 2002. Trascription factors as targets for cancer therapy. Nature Reviews. Cancer 2(10):740-749. https:// doi.org/10.1038/nrc906

Das, R., Bhattacharya, K., Samanta, S. K., Pal, B. C., and Mandal, C. 2014. Improved chemosensitivity in cervical cancer to cisplatin: synergistic activity of mahanine through STAT3 inhibition. Cancer Letters 351(1):81-90. https://doi. org/10.1016/j.canlet.2014.05.005

Das, R., Bhattacharya, K., Sarkar, S., Samanta, S. K., Pal, B. C., and Mandal, C. 2014. Mahanine synergistically enhances cytotoxicity of 5-fluorouracil through ROS-mediated activation of PTEN and p53/p73 in colon carcinoma. Apoptosis 19(1):149-164. https://doi.org/10.1007/s10495-0130907-6

Dhar, S., Kumar, A., Li, K., Tzivion, G., and Levenson, A. S. 2015. Resveratrol regulates PTEN/Akt pathway through inhibition of MTA1/HDAC unit of the NuRD complex in prostate cancer. Biochimica et Biophysica Acta 1853(2):265275. https://doi.org/10.1016/j.bbamcr.2014.11.004

Di, C., Sun, C., Li, H., Si, J., Zhang, H., Han, L., Zhao, Q., Liu, Y., Liu, B., Miao, G., Gan, L., and Liu, Y. 2015. Diallyl disulfide enhances carbon ion beams-induced apoptotic cell death in cervical cancer cells through regulating TAp73 / $\Delta$ Np73. Cell Cycle 14(23):3725-3733. https://doi.org/10.1 080/15384101.2015.1104438

Ding, D. F., Li, X. F., Xu, H., Wang, Z., Liang, Q. Q., Li, C. G., and Wang, Y.J. 2013. Mechanism of resveratrol on the promotion of induced pluripotent stem cells. Journal of Integrative Medicine 11(6):389-396. https://doi.org/10.3736/ jintegrmed2013039

Dokmanovic, M., Clarke, C., and Marks, P. A. 2007. Histone deacetylase inhibitors: overview and perspectives. Molecular Cancer Research 5(10):981-989. https://doi. org/10.1158/1541-7786.MCR-07-0324

Dou, Q.P. 2009. Molecular mechanisms of green tea polyphenols. Nutrition and Cancer 61(6):827-835. https://doi. org/10.1080/01635580903285049

Dyshlovoy, S. A., Fedorov, S. N., Shubina, L. K., Kuzmich, A. S., Bokemeyer, C., Keller-von Amsberg, G., and Honecker, F. 2014. Aaptamines from the marine sponge Aaptos sp. display anticancer activities in human cancer cell lines and modulate AP1-, NF-KB-, and p53-dependent transcriptional activity in mouse JB6 Cl41 cells. BioMed Research International 469309. https://doi. org/10.1155/2014/469309

Easwaran, H., Tsai, H. C., and Baylin, S. B. 2014. Cancer epigenetics: tumor heterogeneity, plasticity of stem-like states, and drug resistance. Molecular Cell 54(5):716-727. https://doi.org/10.1016/j.molcel.2014.05.015

Fang, M., Chen, D., and Yang, C. S. 2007. Dietary polyphenols may affect DNA methylation. The Journal of Nutrition 223S-228S. https://doi.org/10.1093/jn/137.1.223S

Feitelson, M. A., Arzumanyan, A., Kulathinal, R. J., Blain, S. W., Holcombe, R. F., et al. 2015. Sustained proliferation in cancer: Mechanisms and novel therapeutic targets. Seminars in Cancer Biology 35:S25-S54. https://doi. org/10.1016/j.semcancer.2015.02.006

Feng, B., Ng, J. H., Heng, J. C., and Ng, H. H. 2009. Molecules that promote or enhance reprogramming of somatic cells to induced pluripotent stem cells. Cell Stem Cell 4(4):301312. https://doi.org/10.1016/j.stem.2009.03.005

Fraga, M. F., Ballestar, E., Villar-Garea, A., Boix-Chornet, M., Espada, J., Schotta, G., et al. 2005. Loss of acetylation at Lys 16 and trimethylation at Lys 20 of histone $\mathrm{H} 4$ is a common hallmark of human cancer. Nature Genetics 37(4):391-400. https://doi.org/10.1038/ng1531
Fujiwara, Y., Komohara, Y., Ikeda, T., and Takeya, M. 2011. Corosolic acid inhibits glioblastoma cell proliferation by suppressing the activation of signal transducer and activator of transcription-3 and nuclear factor-kappa B in tumor cells and tumor-associated macrophages. Cancer Science 102(1):206-211. https://doi.org/10.1111/j.13497006.2010.01772.x

Furumai, R., Matsuyama, A., Kobashi, N., Lee, K. H., Nishiyama, M., Nakajima, H., Tanaka, A., Komatsu, Y., Nishino, N., Yoshida, M., and Horinouchi, S. 2002. FK228 (depsipeptide) as a natural prodrug that inhibits class I histone deacetylases. Cancer Research 62(17):4916-4921.

Ganapathy, S., Chen, Q., Singh, K. P., Shankar, S., and Srivastava, R. K. 2010. Resveratrol enhances antitumor activity of TRAIL in prostate cancer xenografts through activation of FOXO transcription factor. PLoS One 5(12):e15627. https://doi.org/10.1371/journal.pone.0015627

Gao, Z., Xu, Z., Hung, M. S., Lin, Y. C., Wang, T., Gong, M., Zhi, X., Jablon, D. M., and You, L. 2009. Promoter demethylation of WIF-1 by epigallocatechin-3-gallate in lung cancer cells. Anticancer Research 29(6):2025-2030.

Gerhauser, C. 2013. Cancer chemoprevention and nutriepigenetics: state of the art and future challenges. Topics in Current Chemistry 329:73-132. https://doi. org/10.1007/128_2012_360

Gibbons, R.J. 2005. Histone modifying and chromatin remodelling enzymes in cancer and dysplastic syndromes. Human Molecular Genetics 14:R85-92. https://doi. org/10.1093/hmg/ddi106

Gillespie, S., Borrow, J., Zhang, X. D., and Hersey, P. 2006. Bim plays a crucial role in synergistic induction of apoptosis by the histone deacetylase inhibitor SBHA and TRAIL in melanoma cells. Apoptosis 11:2251-2265. https://doi. org/10.1007/s10495-006-0283-6

Grewal, S. I. and Jia, S. 2007. Heterochromatin revisited. Nature Reviews. Genetics 8(1):35-46. https://doi.org/10.1038/ nrg2008

Guo, H., Xu, Y., and Fu, Q. 2015. Curcumin inhibits growth of prostate carcinoma via miR-208-mediated CDKN1A activation. Tumour Biology 36(11):8511-8517. https://doi. org/10.1007/s13277-015-3592-y

Haack, M., Löwinger, M., Lippmann, D., Kipp, A., Pagnotta, E., Iori, R., Monien, B. H., Glatt, H., Brauer, M. N., Wessjohann, L. A., and Brigelius-Flohé, R. 2010. Breakdown compounds of neoglucobrassicin inhibit activation of Nrf2 target genes mediated by myrosinase-derived glucoraphanin hydrolysis compounds. Biological Chemistry 391(11):1281-1293. https://doi.org/10.1515/BC.2010.134

Hajjouli, S., Chateauvieux, S., Teiten, M. H., Orlikova, B., Schumacher, M., Dicato, M., Choo, C. Y., and Diederich, M. 2014. Eurycomanone and eurycomanol from Eurycoma longifolia Jack as regulators of signaling pathways involved in proliferation, cell death and inflammation. Molecules 19(9):14649-14666. https://doi.org/10.3390/molecules190914649

Halkidou, K., Gaughan, L., Cook, S, Leung, H. Y., Neal, D. E., and Robson, C. N. 2004. Upregulation and nuclear recruitment of HDAC1 in hormone refractory prostate cancer. Prostate 59(2):177-189. https://doi.org/10.1002/ pros.20022

Hassan, M. Q., Tye, C. E., Stein, G. S., and Lian, J. B. 2015. Noncoding RNAs: Epigenetic regulators of bone development and homeostasis. Bone 81:746-756. https://doi. org/10.1016/j.bone.2015.05.026

Henning, S. M., Wang, P., Carpenter, C. L., and Heber, D. 2013. Epigenetic effects of green tea polyphenols in cancer. Epigenomics 5(6):729-741. https://doi.org/10.2217/ epi.13.57 
Henning, S. M., Wang, P., Said, J., Magyar, C., Castor, B., Doan, N., Tosity, C., Moro, A., Gao, K., Li, L., and Heber, D. 2012. Polyphenols in brewed green tea inhibit prostate tumor xenograft growth by localizing to the tumor and decreasing oxidative stress and angiogenesis The Journal of Nutritional Biochemistry. 23(11):1537-1542. https:// doi.org/10.1016/j.jnutbio.2011.10.007

Ho, E., Beaver, L. M., Williams, D. E., and Dashwood, R. H. 2011. Dietary factors and epigenetic regulation for prostate cancer prevention. Advances in Nutrition (Bethesda, Md.) 2(6):497-510. https://doi.org/10.3945/an.111.001032

Hong, K. J., Wu, D. C., Cheng, K. H., Chen, L. T., and Hung, W. C. 2014. RECK inhibits stemness gene expression and tumorigenicity of gastric cancer cells by suppressing ADAM-mediated Notch1 activation. Journal of Cellular Physiology 229(2):191-201. https://doi.org/10.1002/jcp.24434

Huang, J., Plass, C., and Gerhauser, C. 2011. Cancer chemoprevention by targeting the epigenome. Current Drug Targets 12(13):1925-1956. https://doi. org/10.2174/138945011798184155

Huang, M. T., Newmark, H. L., and Frenkel, K. 1997. Inhibitory effects of curcumin on tumorigenesis in mice. Journal of Cellular Biochemistry 27:26-34. https://doi. org/10.1002/(SICI)1097-4644(1997)27+\%3C26::AIDJCB7\%3E3.0.CO;2-3

Huisinga, K. L., Brower-Toland, B., and Elgin, S. C. 2006. The contradictory definitions of heterochromatin: transcription and silencing. Chromosoma 115(2):110-122. https:// doi.org/10.1007/s00412-006-0052-x

Jandial, D. D., Blair, C. A., Zhang, S., Krill, L. S., Zhang, Y. B., and $\mathrm{Zi}, \mathrm{X} .2014$. Molecular targeted approaches to cancer therapy and prevention using chalcones. Current Cancer Drug Targets 14(2):181-200. https://doi.org/10.2174/156 8009614666140122160515

Jenuwein, T. and Allis, C. D. 2001. Translating the histone code. Science 293(5532):1074-1080. https://doi.org/10.1126/ science. 1063127

Jia, Y. and Guo, M. 2013. Epigenetic changes in colorectal cancer. Chinese Journal of Cancer 32(1):21-30. https://doi. org/10.5732/cjc.011.10245

Jones, P. A. and Baylin, S. B. 2007. The epigenomics of cancer. Cell 128(4):683-692. https://doi.org/10.1016/j. cell.2007.01.029

Kai, L., Samuel, S. K., and Levenson, A. S. 2010. Resveratrol enhances $\mathrm{p} 53$ acetylation and apoptosis in prostate cancer by inhibiting MTA1/NuRD complex. International Journal of Cancer 126(7):1538-1548. https://doi.org/10.1002/ ijc. 24928

Kao, C.L., Cho, J., Lee, Y.Z., Cheng, Y.B., Chien, C.Y., Hwang, C. F., Hong, Y.R., Tseng, C. N., and Cho, C.L. 2015. Ethanolic extracts of Pluchea indica induce apoptosis and antiproliferation effects in human nasopharyngeal carcinoma cells. Molecules 20(6):11508-11523. https://doi.org/10.3390/molecules200611508

Kato, K., Long, N. K., Makita, H., Toida, M., Yamashita, T., Hatakeyama, D., Hara, A., Mori, H., and Shibata, T. 2008. Effects of green tea polyphenol on methylation status of RECK gene and cancer cell invasion in oral squamous cell carcinoma cells. British Journal of Cancer 99(4):647654. https://doi.org/10.1038/sj.bjc.6604521

Khoury, G.A., Baliban, R. C., and Floudas, C.A. 2011. Proteome-wide post-translational modification statistics: frequency analysis and curation of the swiss-prot database. Scientific Reports 1:90. https://doi.org/10.1038/ srep00090

Kikuno, N., Shiina, H., Urakami, S., Kawamoto, K., Hirata, H., Tanaka, Y., Majid, S., Igawa, M., and Dahiya, R. 2008. Mediated histone acetylation and demethylation activates tumor suppressor genes in prostate cancer cells. International Journal of Cancer 123(3):552-560. https://doi. org/10.1002/ijc.23590

Kim, H. J. and Bae, S. C. 2011. Histone deacetylase inhibitors: molecular mechanisms of action and clinical trials as anti-cancer drugs. American Journal of Transational Research 3(2):166-179.

Kim, S. M., Lee, J. H., Sethi, G., Kim, C., Baek, S. H., Nam, D., Chung, W. S., Kim, S. H., Shim, B. S., and Ahn, K. S. 2014. Bergamottin, a natural furanocoumarin obtained from grapefruit juice induces chemosensitization and apoptosis through the inhibition of STAT3 signaling pathway in tumor cells. Cancer Letters 354(1):153-163. https://doi. org/10.1016/j.canlet.2014.08.002

Kim, Y.Z. 2014. Altered histone modifications in gliomas. Brain Tumor Research and Treatment 2(1):7-21. https:// doi.org/10.14791/btrt.2014.2.1.7

Kong, D., Heath, E., Chen, W., Cher, M. L., Powell, I., HeiIbrun, L., Li, Y., Ali, S., Sethi, S., Hassan, O., Hwang, C., Gupta, N., Chitale, D., Sakr, W. A., Menon, M., and Sarkar, F. H. 2012. Loss of let-7 up-regulates EZH2 in prostate cancer consistent with the acquisition of cancer stem cell signatures that are attenuated by BR-DIM. PLoS One 7(3):e33729. https://doi.org/10.1371/journal. pone.0033729

Konstantinopoulos, P.A., Vandoros, G.P., and Papavassiliou, A. G. 2006. FK228 (depsipeptide): a HDAC inhibitor with pleiotropic antitumor activities. Cancer Chemotherapy and Pharmacology 58(5):711-715. https://doi. org/10.1007/s00280-005-0182-5

Krishnan, M., Singh, A. B., Smith, J.J., Sharma, A., Chen, X., Eschrich, S., Yeatman, T.J., Beauchamp, R. D., and Dhawan, P. 2010. HDAC inhibitors regulate claudin-1 expression in colon cancer cells through modulation of mRNA stability. Oncogene 29(2):305-312. https://doi. org/10.1038/onc.2009.324

Lee, E. Y. and Muller, W.J. 2010. Oncogenes and tumor suppressor genes. Cold Spring Harbor Perspectives in Biology 2(10):a003236. https://doi.org/10.1101/cshperspect. a003236

Lee, J. S. 2007. Functional link between DNA damage responses and transcriptional regulation by ATM in response to a histone deacetylase inhibitor TSA. Cancer Research and Treatment: Official Journal of Korean Cancer Association 39:116-124. https://doi.org/10.4143/crt.2007.39.3.116

Lee, T.I. and Young, R. A. 2013. Transcriptional regulation and its misregulation in disease. Cell 152(6):1237-1251. https://doi.org/10.1016/j.cell.2013.02.014

Lee, W. J., Shim, J. Y., and Zhu, B. T. 2005. Mechanisms for the inhibition of DNA methyltransferases by tea catechins and bioflavonoids. Molecular Pharmacology 68(4):10181030. https://doi.org/10.1124/mol.104.008367

Levenson, A. S., Kumar, A., and Zhang, X. 2014. MTA family of proteins in prostate cancer: biology, significance, and therapeutic opportunities. Cancer Metastasis Reviews 33(4):929-942. https://doi.org/10.1007/s10555-0149519-z

Li, B., Zhao, J., Wang, C. Z., Searle, J., He, T. C., Yuan, C. S., and Du, W. 2011. Ginsenoside Rh2 induces apoptosis and paraptosis-like cell death in colorectal cancer cells through activation of p53. Cancer Letters 301(2):185-192. https://doi.org/10.1016/j.canlet.2010.11.015

Li, K., Dias, S. J., Rimando, A. M., Dhar, S., Mizuno, C. S., Penman, A. D., Lewin, J. R., and Levenson, A. S. 2013. Pterostilbene acts through metastasis-associated protein 1 to inhibit tumor growth, progression and metastasis in prostate cancer. PLOS One 8(3):e57542. https://doi. org/10.1371/journal.pone.0057542 
Li, Y., Kong, D., Wang, Z., and Sarkar, F. H. 2010. Regulation of microRNAs by natural agents: an emerging field in chemoprevention and chemotherapy research. Pharmaceutical Research 27(6):1027-1041. https://doi.org/10.1007/ s11095-010-0105-y

Lin, J. K. 2007. Molecular targets of curcumin. Advances in Experimental Medicine and Biology 595:227-243. https:// doi.org/10.1007/978-0-387-46401-5_10

Link, A., Balaguer, F., and Goel, A. 2010.Cancer chemoprevention by dietary polyphenols: promising role for epigenetics. Biochemical Pharmacology 80(12):1771-1792. https://doi.org/10.1016/j.bcp.2010.06.036

Liu, H. L., Chen, Y., Cui, G. H., and Zhou, J. F. 2005. Curcumin, a potent anti-tumor reagent, is a novel histone deacetylase inhibitor regulating B-NHL cell line Raji proliferation. Acta Pharmacologica Sinica 26(5):603-609. https://doi. org/10.1111/j.1745-7254.2005.00081.x

Liu, J. D., Chen, S. H., Lin, C. L., Tsai, S. H., and Liang, Y. C. 2001. Inhibition of melanoma growth and metastasis by combination with (-)-epigallocatechin-3-gallate and dacarbazine in mice. Journal of Cellular Biochemistry 83(4):631642. https://doi.org/10.1002/jcb.1261

Liu, Z., Xie, Z., Jones, W., Pavlovicz, R. E., Liu, S., Yu, J., Li, P. K., Lin, J., Fuchs, J. R., Marcucci, G., Li, C., and Chan, K. K. 2009. Curcumin is a potent DNA hypomethylation agent. Bioorganic \& Medicinal Chemistry Letters 19(3):706-709. https://doi.org/10.1016/j.bmcl.2008.12.041

Lizcano, F. and Garcia, J. 2012. Epigenetic control and cancer: the potential of histone demethylases as therapeutic targets. Pharmaceuticals 5(9):963-999. https://doi. org/10.3390/ph5090963

Losson, H., Schnekenburger, M., Dicato, M., and Diederich, M. 2016. Natural compound histone deacetylase inhibitors (HDACi): Synergy with inflammatory signaling pathway modulators and clinical applications in cancer. Molecules 21(11):1608. https://doi.org/10.3390/molecules21111608

Lou, C., Takahashi, K., Irimura, T., Saiki, I., and Hayakawa, Y. 2014. Identification of Hirsutine as an anti-metastatic phytochemical by targeting NF-kB activation. International Journal of Oncology 45(5):2085-2091. https://doi. org/10.3892/ijo.2014.2624

Lu, Q.Y., Jin, Y. S., Zhang, Z.F., Le, A. D., Heber, D., Li, F. P., Dubinett, S. M., and Rao, J.Y. 2007. Green tea induces annexin-I expression in human lung adenocarcinoma A549 cells: involvement of annexin-I in actin remodeling. Laboratory Investigation 87(5):456-465. https://doi. org/10.1038/labinvest.3700534

Luo, X., Yu, X., Liu, S., Deng, Q., Liu, X., Peng, S., Li, H., Liu, J., and Cao, Y. 2015. The role of targeting kinase activity by natural compounds in cancer chemoprevention and chemotherapy. Oncology Reports 34(2):547-554. https:// doi.org/10.3892/or.2015.4029

Ma, N., Luo, Y., Wang, Y., Liao, C., Ye, W. C., and Jiang, S. 2016 Selective histone deacetylase inhibitors with anticancer activity. Current Topics in Medicinal Chemistry 16(4):415-426. https://doi.org/10.2174/1568026615666150813145629

Manal, M., Chandrasekar, M., Jeyapal, G. P., and Nanjan, M. 2016. Inhibitors of histone deacetylase as antitumor agents: A critical review. Bioorganic Chemistry 67:18-42. https://doi.org/10.1016/j.bioorg.2016.05.005

Marks, P.A. 2010. The clinical development of histone deacetylase inhibitors as targeted anticancer drugs. Expert Opinion on Investigational Drugs 19(9):1049-1066. https://doi.org/10.1517/13543784.2010.510514

Marquardt, J. U., Gomez-Quiroz, L., Arreguin Camacho, L. O., Pinna, F., Lee, Y. H., Kitade, M., Domínguez, M. P., Castven, D., Breuhahn, K., Conner, E. A., Galle, P. R., Ander- sen, J. B., Factor, V. M., and Thorgeirsson, S. S. 2015. Curcumin effectively inhibits oncogenic NF-kB signaling and restrains stemness features in liver cancer. Journal of Hepatology 63(3):661-669. https://doi.org/10.1016/j. jhep.2015.04.018

Mayboroda, A. A. 2013. Genes and proteins of oncogenesis. Sibirskiy meditsinskiy zhurnal 2:132-138. (In Russian)

Maze, I., Wenderski, W., Noh, K. M., Bagot, R. C., Tzavaras, N., et al. 2015. Critical role of histone turnover in neuronal transcription and plasticity. Neuron 87(1):77-94. https:// doi.org/10.1016/j.neuron.2015.06.014

Medina-Franco, J. L., López-Vallejo, F., Kuck, D., and Lyko, F. 2011. Natural compounds as DNA methyltransferase inhibitors: a computer-aided discovery approach. Molecular Diversity 15(2):293-304. https://doi.org/10.1007/ s11030-010-9262-5

Meeran, S. M., Patel, S. N., and Tollefsbol, T. O. 2010. Sulforaphane causes epigenetic repression of human TERT expression in human breast cancer cell lines. PLoS One 5(7):e11457. https://doi.org/10.1371/journal. pone.0011457

Minucci, S. and Pelicci, P. G. 2006. Histone deacetylase inhibitors and the promise of epigenetic (and more) treatments for cancer. Nature Reviews. Cancer 6:38-51. https://doi.org/10.1038/nrc1779

Mitani, T., Harada, N., Tanimori, S., Nakano, Y., Inui, H., and Yamaji, R. 2014. Resveratrol inhibits hypoxia-inducible factor-1a-mediated androgen receptor signaling and represses tumor progression in castration-resistant prostate cancer. Journal of Nutritional Science and Vitaminology 60(4):276-282. https://doi.org/10.3177/jnsv.60.276

Mitani, T., Ito, Y., Harada, N., Nakano, Y., Inui, H., Ashida, H., and Yamaji, R. 2014. Resveratrol reduces the hypoxiainduced resistance to doxorubicin in breast cancer cells. Journal of Nutritional Science and Vitaminology 60(2):122128. https://doi.org/10.3177/jnsv.60.122

Moghadamtousi, S. Z., Kadir, H. A., Paydar, M., Rouhollahi, E., and Karimian, H. 2014. Annona muricata leaves induced apoptosis in A549 cells through mitochondrial-mediated pathway and involvement of NF-kB. BMC Complementary and Alternative Medicine 14:299. https://doi. org/10.1186/1472-6882-14-299

Morey, L., Santanach, A., and Di Croce, L. 2015. Pluripotency and epigenetic factors in mouse embryonic stem cell fate regulation. Molecular and Cell Biology 35(16):27162728. https://doi.org/10.1128/MCB.00266-15

Moseley, V.R., Morris, J., Knackstedt, R. W., and Wargovich, M. J. 2013. Green tea polyphenol epigallocatechin. Anticancer Research 33(12):5325-5333.

Mudduluru, G., George-William, J. N., Muppala, S., Asangani, I. A., Kumarswamy, R., Nelson, L. D., and Allgayer, H. 2011. Curcumin regulates miR-21 expression and inhibits invasion and metastasis in colorectal cancer. Bioscience Reports 31(3):185-197. https://doi.org/10.1042/ BSR20100065

Mukhopadhyay, A., Bueso-Ramos, C., Chatterjee, D., Pantazis, P., and Aggarwal, B. B. 2001. Curcumin downregulates cell survival mechanisms in human prostate cancer cell lines. Oncogene 20(52):7597-7609. https://doi. org/10.1038/sj.onc.1204997

Murugan, R. S., Vinothini, G., Hara, Y., and Nagini, S. 2009. Black tea polyphenols target matrix metalloproteinases, RECK, proangiogenic molecules and histone deacetylase in a rat hepatocarcinogenesis model. Anticancer Research 29(6):2301-2305.

Nakayama, J., Rice, J.C., Strahl, B.D., Allis, C. D., and Grewal, S. I. 2001. Role of histone H3 lysine 9 methylation in epigenetic control of heterochromatin assembly. 
Science 292(5514):110-113. https://doi.org/10.1126/science. 1060118

Nandakumar, V., Vaid, M., and Katiyar, S. K. 2011. (-)-Epigallocatechin-3-gallate reactivates silenced tumor suppressor genes, Cip1/p21 and p16INK4a, by reducing DNA methylation and increasing histones acetylation in human skin cancer cells. Carcinogenesis 32(4):537-544. https://doi.org/10.1093/carcin/bgq285

Neergheen-Bhujun, V., Taj Awan, A., Baran, Y., et al. 2017. Biodiversity, drug discovery, and the future of global health: Introducing the biodiversity to biomedicine consortium, a call to action. Journal of Global Health 7(2):020304. https://doi.org/10.7189/jogh.07.020304

Newman, D.J. and Cragg, G. M. 2007. Natural products as sources of new drugs over the last 25 years. Journal of Natural Products 70(3):461-477. https://doi.org/10.1021/ np068054v

Orlikova, B., Schumacher, M., Juncker, T., Yan, C. C., InayatHussain, S. H., Hajjouli, S., Cerella, C., Dicato, M., and Diederich, M. 2013. Styryl-lactone goniothalamin inhibits TNF-a-induced NF-KB activation. Food and Chemical Toxicology: An International Journal Published for the British Industrial Biological Research Association 59:572-578. https://doi.org/10.1016/j.fct.2013.06.051

Pandey, M., Shukla, S., and Gupta, S. 2010. Promoter demethylation and chromatin remodeling by green tea polyphenols leads to re-expression of GSTP1 in human prostate cancer cells. International Journal of Cancer 126(11):25202533. https://doi.org/10.1002/ijc.24988

Park, C. H., Lee, J. H., and Yang, C. H. 2005. Curcumin derivatives inhibit the formation of Jun-Fos-DNA complex independently of their conserved cysteine residues. Journal of Biochemistry and Molecular Biology 38(4):474-480. https://doi.org/10.5483/BMBRep.2005.38.4.474

Paszkowski, J. and Whitham, S. 2001. Gene silencing and DNA methylation processes. Current Opinion in Plant Biology 4(2):123-129. https://doi.org/10.1016/S13695266(00)00147-3

Pera, B., Tang, T., Marullo, R., Yang, S. N., Ahn, H., Patel, J., Elstrom, R., Ruan, J., Furman, R., Leonard, J., Cerchietti, L., and Martin, P. 2016. Combinatorial epigenetic therapy in diffuse large B cell lymphoma pre-clinical models and patients. Clinical Epigenetics 8:79. https://doi.org/10.1186/ s13148-016-0245-y

Pietrocola, F., Mariño, G., Lissa, D., Vacchelli, E., Malik, S. A., Niso-Santano, M., Zamzami, N., Galluzzi, L., Maiuri, M. C., and Kroemer, G. 2012. Pro-autophagic polyphenols reduce the acetylation of cytoplasmic proteins. Cell Cycle 11(20):3851-3860. https://doi.org/10.4161/cc.22027

Pradhan, S. J., Mishra, R., Sharma, P., and Kundu, G. C. 2010. Quercetin and sulforaphane in combination suppress the progression of melanoma through the downregulation of matrix metalloproteinase-9. Experimental and Therapeutic Medicine 1(6):915-920. https://doi. org/10.3892/etm.2010.144

Pratheeshkumar, P., Sreekala, C., Zhang, Z., Budhraja, A., Ding, S., Son, Y. O., Wang, X., Hitron, A., Hyun-Jung, K., Wang, L., Lee, J. C., and Shi, X. 2012. Cancer prevention with promising natural products: mechanisms of action and molecular targets. Anticancer Agents in Medicinal Chemistry 12(10):1159-1184. https://doi. org/10.2174/187152012803833035

Prusty, B.K. and Das, B.C. 2005. Constitutive activation of transcription factor AP-1 in cervical cancer and suppression of human papillomavirus (HPV) transcription and AP-1 activity in HeLa cells by curcumin. International Journal of Cancer 113(6):951-960. https://doi.org/10.1002/ ijc.20668
Rahman, K. M., Sarkar, F. H., Banerjee, S., Wang, Z., Liao, D. J., Hong, X., and Sarkar, N. H. 2006. Therapeutic intervention of experimental breast cancer bone metastasis by indole-3-carbinol in SCID-human mouse model. Molecular Cancer Therapeutics 5(11):2747-2756. https://doi. org/10.1158/1535-7163.MCT-06-0221

Rea, S., Eisenhaber, F., O'Carroll, D., Strahl, B. D., Sun, Z. W., Schmid, M., Opravil, S., Mechtler, K., Ponting, C. P., Allis, C. D., and Jenuwein, T. 2000. Regulation of chromatin structure by site-specific histone $\mathrm{H} 3$ methyltransferases. Nature 406(6796):593-599. https://doi. org/10.1038/35020506

Roy, S. K., Chen, Q., Fu, J., Shankar, S., and Srivastava, R. K. 2011. Resveratrol inhibits growth of orthotopic pancreatic tumors through activation of FOXO transcription factors. PLoS One 6(9):e25166. https://doi.org/10.1371/ journal.pone.0025166

Royston, K.J. and Tollefsbol, T. O. 2015. The epigenetic impact of cruciferous vegetables on cancer prevention. Current Pharmacology Reports 1(1):46-51. https://doi. org/10.1007/s40495-014-0003-9

Rummun, N., Hughes, R. E., Beesoo, R., Li, W. W., et al. 2019. Mauritian endemic medicinal plant extracts induce G2/M phase cell cycle arrest and growth inhibition of oesophageal squamous cell carcinoma in vitro. Acta $\mathrm{Na}$ turae 11(1):81-90. https://doi.org/10.32607/207582512019-11-1-81-90

Safa, M., Tavasoli, B., Manafi, R., Kiani, F., Kashiri, M., Ebrahimi, S., and Kazemi, A. 2015. Indole-3-carbinol suppresses NF-KB activity and stimulates the p53 pathway in pre-B acute lymphoblastic leukemia cells. Tumour Biology: The Journal of the International Society for Oncodevelopmental Biology and Medicine 36(5):3919-3930. https:// doi.org/10.1007/s13277-014-3035-1

Saha, K., Hornyak, T.J., and Eckert, R. L. 2013. Epigenetic cancer prevention mechanisms in skin cancer. An Official Journal of the American Association of Pharmaceutical Scientists 15(4):1064-1071. https://doi.org/10.1208/ s12248-013-9513-3

Samantarrai, D., Dash, S., Chhetri, B., and Mallick, B. 2013. Genomic and epigenomic cross-talks in the regulatory landscape of miRNAs in breast cancer. Molecular Cancer Research 4:315-328. https://doi.org/10.1158/1541-7786

Santos, F. P., Kantarjian, H., Garcia-Manero, G., Issa, J. P., and Ravandi, F. 2010. Decitabine in the treatment of myelodysplastic syndromes. Expert Review of Anticancer Therapy 10(1):9-22. https://doi.org/10.1586/era.09.164

Schubert, T. and Langst, G. 2015. Study of epigenetic interactions using Microscale Thermophoresis (MST). AIMS Biophysics 2(3):370-380. https://doi.org/10.3934/biophy.2015.3.370

Seligson, D. B., Horvath, S., Shi, T., Yu, H., Tze, S., Grunstein, M., and Kurdistani, S. K. 2005. Global histone modification patterns predict risk of prostate cancer recurrence. $\mathrm{Na}$ ture 435(7046):1262-1266. https://doi.org/10.1038/nature03672

Shankar, S., Nall, D., Tang, S. N., Meeker, D., Passarini, J., Sharma, J., and Srivastava, R. K. 2011. Resveratrol inhibits pancreatic cancer stem cell characteristics in human and KrasG12D transgenic mice by inhibiting pluripotency maintaining factors and epithelial-mesenchymal transition. PLoS One 6(1):e16530. https://doi.org/10.1371/ journal.pone.0016530

Shi, Y., Dong, M., Hong, X., Zhang, W., Feng, J., Zhu, J., Yu, L., Ke, X., Huang, H., Shen, Z., Fan, Y., Li, W., Zhao, X., et al. 2015. Results from a multicenter, open-label, pivotal phase II study of chidamide in relapsed or refractory peripheral T-cell lymphoma. Annals of Oncology: Of- 
ficial Journal of the European Society for Medical Oncology 26(8):1766-1771. https://doi.org/10.1093/annonc/ $\mathrm{mdv} 237$

Shukla, S., Meeran, S. M., and Katiyar, S. K. 2014. Epigenetic regulation by selected dietary phytochemicals in cancer chemoprevention. Cancer Letters 355(1):9-17. https:// doi.org/10.1016/j.canlet.2014.09.017

Siddiqui, I. A., Adhami, V. M., Saleem, M., and Mukhtar, H. 2006.Beneficial effects of tea and its polyphenols against prostate cancer. Molecular Nutrition \& Food Research 50(2):130-143. https://doi.org/10.1002/mnfr.200500113

Song, J., Noh, J. H., Lee, J. H., Eun, J. W., Ahn, Y. M., Kim, S. Y., Lee, S.H., et al. 2005. Increased expression of histone deacetylase 2 is found in human gastric cancer. APMIS: Acta Pathologica, Microbiologica, et Immunologica Scandinavica 113(4):264-268. https://doi. org/10.1111/j.1600-0463.2005.apm_04.x

Su, Z. Y., Khor, T. O., Shu, L., Lee, J. H., Saw, C. L., Wu, T.Y., Huang, Y., et al. 2013. Epigenetic reactivation of Nrf2 in murine prostate cancer TRAMP C1 cells by natural phytochemicals Z-ligustilide and Radix angelica sinensis via promoter CpG demethylation. Chemical Research in Toxicology 26(3):477-485. https://doi.org/10.1021/ tx300524p

Subramaniam, D., Ponnurangam, S., Ramamoorthy, P., Standing, D., Battafarano, R.J., Anant, S., and Sharma, P. 2012. Curcumin induces cell death in esophageal cancer cells through modulating Notch signaling. PloS One 7(2):e30590. https://doi.org/10.1371/journal. pone.0030590

Sui, X., Zhu, J., Zhou, J., et al. 2015. Epigenetic modifications as regulatory elements of autophagy in cancer. Cancer Letters 360(2):106-113. https://doi.org/10.1016/j.canlet.2015.02.009

Sun, L., Zhou, W., Zhang, H., Guo, Q., Yang, W., Li, B., Sun, Z., Gao, S., and Cui, R. 2019. Modulation of multiple signaling pathways of the plant-derived natural products in cancer. Frontiers in Oncology 9:1153. https://doi. org/10.3389/fonc.2019.01153

Sutherland, J. and Costa, M. 2003. Epigenetics and the environment. Annals of the New York Academy of Sciences 983:151-160. https://doi.org/10.1111/j.1749-6632.2003. tb05970.x

Taby, R. and Issa, J. P. 2010. Cancer epigenetics. CA: A Cancer Journal for Clinicians 60(6):376-392. https://doi. org/10.3322/caac.20085

Teif, V. and Rippe, K. 2011. Nucleosome mediated crosstalk between transcription factors at eukaryotic enhancers. Physical Biology 8(4):044001. https://doi. org/10.1088/1478-3975/8/4/044001

Teiten, M. H., Eifes, S., Dicato, M., and Diederich, M. 2010. Curcumin - the paradigm of a multi-target natural compound with applications in cancer prevention and treatment. Toxins 2(1):128-162. https://doi.org/10.3390/ toxins 2010128

Teiten, M.H., Gaascht, F., Eifes, S., Dicato, M., and Diederich, M. 2010. Chemopreventive potential of curcumin in prostate cancer. Genes \& Nutrition 5(1):61-74. https:// doi.org/10.1007/s12263-009-0152-3

Thakur, V.S., Deb, G., Babcook, M.A., and Gupta, S. 2014. Plant phytochemicals as epigenetic modulators: role in cancer chemoprevention. The AAPS Journal 16(1):151163. https://doi.org/10.1208/s12248-013-9548-5

Toden, S., Okugawa, Y., Buhrmann, C., Nattamai, D., Anguiano, E., Baldwin, N., Shakibaei, M., Boland, C. R., and Goel, A. 2015. Novel evidence for curcumin and boswellic acid-induced chemoprevention through regulation of miR-34a and miR-27a in colorectal cancer.
Cancer Prevention Research 8(5):431-443. https://doi. org/10.1158/1940-6207.CAPR-14-0354

Traka, M., Gasper, A. V., Smith, J. A., Hawkey, C. J., Bao, Y., and Mithen, R. F. 2005. Transcriptome analysis of human colon Caco-2 cells exposed to sulforaphane. The Journal of Nutrition 135(8):1865-1872. https://doi.org/10.1093/ jn/135.8.1865

Tuntiwechapikul, W., Taka, T., Songsomboon, C., Kaewtunjai, N., Imsumran, A., Makonkawkeyoon, L., Pompimon, W., and Lee, T.R. 2010. Ginger extract inhibits human telomerase reverse transcriptase and c-Myc expression in A549 lung cancer cells. Journal of Medical Food 13(6):1347-1354. https://doi.org/10.1089/jmf.2010.1191

Udugama, M., Chang, F.T.M., Chan, F. L., et al. 2015. Histone variant $\mathrm{H} 3.3$ provides the heterochromatic $\mathrm{H} 3$ lysine 9 tri-methylation mark at telomeres. Nucleic Acids Research 43(21):10227-10237. https://doi.org/10.1093/ nar/gkv847

Urnov, F. D. and Wolffe, A. P. 2001. Above and within the genome: epigenetics past and present. Journal of Mammary Gland Biology and Neoplasia 6(2):153-167. https://doi. org/10.1023/A:1011304606604

Venkatasubramani, A. V., McLaughlin, K., Blanco, R. G., Larionov V., and Kagansky, A. 2015. The pilot screening RNA using the system based on mammalian cells reveals new putative silencing factors, including Kat5 / Tip60. AIMS Biophysics 2(4):570-584. https://doi.org/10.3934/ biophy.2015.4.570

Verhoeven, D.T., Verhagen, H., Goldbohm, R.A., van den Brandt, P. A., van Poppel, G. 1997. A review of mechanisms underlying anticarcinogenicity by brassica vegetables Chemico-biological Interactions 103(2):79-129. https://doi.org/10.1016/s0009-2797(96)03745-3

Volate, S. R., Muga, S. J., Issa, A. Y., Nitcheva, D., Smith, T., and Wargovich, M.J. 2009. Epigenetic modulation of the retinoid $X$ receptor alpha by green tea in the azoxymethaneApc Min/+ mouse model of intestinal cancer. Molecular Carcinogenesis 48(10):920-933. https://doi.org/10.1002/ mc.20542

Wai-Leng, L., Jing-Ying, H., and Lie-Fen, S. 2013. Phytoagents for cancer management: Regulation of nucleic acid oxidation, ROS, and related mechanisms. Oxidative Medicine and Cellular Longevity 925804. https://doi. org/10.1155/2013/925804

Wang, J., Xie, H., Gao, F., Zhao, T., Yang, H., and Kang, B. 2016. Curcumin induces apoptosis in p53-null Hep3B cells through a TAp73/DNp73-dependent pathway. Tumour biology: The Journal of the International Society for Oncodevelopmental Biology and Medicine 37(3):4203-4212. https://doi.org/10.1007/s13277-015-4029-3

Wang, L. G., Beklemisheva, A., Liu, X. M., Ferrari, A. C., Feng, J., and Chiao, J. W. 2007. Dual action on promoter demethylation and chromatin by an isothiocyanate restored GSTP1 silenced in prostate cancer Molecular Carcinogenesis 46(1):24-31. https://doi.org/10.1002/mc.20258

Wang, L., Liou, J., Li, Y., Liu, Y., Pan, S., and Teng, C. 2014. A novel class I HDAC inhibitor, MPT0G030, induces cell apoptosis and differentiation in human colorectal cancer cells via HDAC1/PKC $\delta$ and E-cadherin. Oncotarget 5:5651-5662. https://doi.org/10.18632/oncotarget.2155

Wang, Y., Li, Y., Liu, X., and Cho, W. C. 2013. Genetic and epigenetic studies for determining molecular targets of natural compound anticancer agents. Current Cancer Drug Targets 13(5):506-518. https://doi.org/10.2174/1568009 6113139990033

Weichert, W., Roske, A., Niesporek, S., Noske, A., Buckendahl, A. C., Dietel, M., Gekeler, V., Boehm, M., Beckers, T., and Denkert, C. 2008. Class I histone deacetylase ex- 
pression has independent prognostic impact in human colorectal cancer: specific role of class I histone deacetylases in vitro and in vivo. Clinical Cancer Research 14(6):1669-1677. https://doi.org/10.1158/1078-0432

West, A.C. and Johnstone, R.W. 2014. New and emerging HDAC inhibitors for cancer treatment. The Journal of Clinical Investigation 124(1):30-39. https://doi.org/10.1172/ JCl69738

Wilson, A. J., Byun, D. S., Popova, N., Murray, L. B., L'Italien, K., Sowa, Y., et al. 2006. Histone deacetylase 3 (HDAC3) and other class I HDACs regulate colon cell maturation and p21 expression and are deregulated in human colon cancer. The Journal of Biological Chemistry 281(19):1354813558. https://doi.org/10.1074/jbc.M510023200

Wong, C.P., Hsu, A., Buchanan, A., Palomera-Sanchez, Z., Beaver, L. M., Houseman, E. A., Williams, D. E., Dashwood, R. H., and Ho, E. 2014. Effects of sulforaphane and 3,3'-diindolylmethane on genome-wide promoter methylation in normal prostate epithelial cells and prostate cancer cells. PLoS One 9(1):e86787. https://doi. org/10.1371/journal.pone.0086787

Woo, H. J., Lee, S. J., Choi, B. T., Park, Y. M., and Choi, Y. H. 2007. Induction of apoptosis and inhibition of telomerase activity by trichostatin A, a histone deacetylase inhibitor, in human leukemic U937 cells. Experimental and Molecular Pathology 82(1):77-84. https://doi.org/10.1016/j. yexmp.2006.02.004

Xiao, G. S., Jin, Y. S., Lu, Q. Y., Zhang, Z. F., Belldegrun, A. et al. 2007. Annexin-I as a potential target for green tea extract induced actin remodeling. International Journal of Cancer 120(1):111-120. https://doi.org/10.1002/ijc.22164

Ye, M., Zhang, J., Zhang, J., Miao, Q., Yao, L., and Zhang, J. 2015. Curcumin promotes apoptosis by activating the p53-miR-192-5p/215-XIAP pathway in non-small cell lung cancer. Cancer Letters 357(1):196-205. https://doi. org/10.1016/j.canlet.2014.11.028

Yoon, D. S., Choi, Y., Jang, Y., Lee, M., Choi, W. J., Kim, S. H., and Lee, J. W. 2014. SIRT1 directly regulates SOX2 to maintain self-renewal and multipotency in bone marrow-derived mesenchymal stem cells. Stem Cells 32(12):3219-3231. https://doi.org/10.1002/stem.1811
Yu, X. D. and Guo, Z. S. 2010 Epigenetic drugs for cancer treatment and prevention: mechanisms of action. Biomolecular Concepts 1(3-4):239-251. https://doi.org/10.1515/ bmc. 2010.020

Zang, S., Liu, T., Shi, J., and Qiao, L. 2014. Curcumin: a promising agent targeting cancer stem cells. Anti-cancer Agents in Medicinal Chemistry 14(6):787-792. https://doi.org/10. 2174/1871520614666140521114735

Zaridze, D. G. 2004 in Carcinogenesis (Zaridze, D. G., ed.), Meditsina, Moscow, pp. 29-85. (In Russian)

Zhang, M., Bian, Z. G., Zhang, Y., Wang, J. H., Kan, L., Wang, X., Niu, H. Y., He, P. 2014. Cucurbitacin B inhibits proliferation and induces apoptosis via STAT3 pathway inhibition in A549 lung cancer cells. Molecular Medicine Reports 10(6):2905-2911. https://doi.org/10.3892/mmr.2014.2581

Zhang, Z., Yamashita, H., Toyama, T., Sugiura, H., Ando, Y., Mita, K., Hamaguchi, M., Hara, Y., Kobayashi, S., and Iwase, H. 2005. Quantitation of HDAC1 mRNA expression in invasive carcinoma of the breast*. Breast Cancer Research and Treatment 94(1):11-16. https://doi. org/10.1007/s10549-005-6001-1

Zhao, Y., Tan, J., Zhuang, L., Jiang, X., Liu, E.T., and Yu, Q. 2005. Inhibitors of histone deacetylases target the Rb-E2F1 pathway for apoptosis induction through activation of proapoptotic protein Bim. Proceedings of the National Academy of Sciences of the United States of America 102:16090-16095. https://doi.org/10.1073/ pnas.0505585102

Zhdanov, R., Schirmer, E. C., Venkatasubramani A. V., et al. 2015. Lipids contribute to epigenetic control via chromatin structure and functions. Science Open Research 10(15). https:// doi.org/10.14293/S2199-1006.1.SOR-LIFE.AUXYTR.v1

Zhu, P., Martin, E. Mengwasser, J., Schlag, P., Janssen, K. P., and Gottlicher, M. 2004. Induction of HDAC2 expression upon loss of APC in colorectal tumorigenesis. Cancer Cell 5(5):455-463. https://doi.org/10.1016/S15356108(04)00114-X

Zwergel, C., Valente, S., Jacob, C., and Mai, A. 2015. Emerging approaches for histone deacetylase inhibitor drug discovery. Expert Opinion on Drug Discovery 10(6):599-613. https://doi.org/10.1517/17460441.2015.1038236 